\title{
GUIDELINE
}

\section{Renal palliative and supportive care in South Africa - a consensus statement}

\begin{abstract}
Compiled by: Prof Nicola Wearne', Dr Rene Krause², Dr Bianca Davidson', Dr Frank Brennan³
Scribe: Prof Liz Gwyther ${ }^{2}$

Contributors: Dr M Abbas', Dr Z Barday', Dr A Barnard², Dr K Bezuidenhout ${ }^{5}$, Prof M Blockman6, Dr L Bloemhof ${ }^{4}$, Mr B Bidii',

Dr MY Chothia 7 , Dr C Cox ${ }^{4}$, Prof MR Davids ${ }^{7}$, Dr S De Bruin ${ }^{4}$, Dr E de Vries ${ }^{8}$, Dr B Eick', Dr J Ensor ${ }^{10}$, Dr K Evans ${ }^{\prime \prime}$,

$\operatorname{Dr} C$ February ${ }^{12}$, Dr N Fouche ${ }^{12}$, Dr R Freercks ${ }^{10}$, Dr P Gajjar ${ }^{13}$, Ms R Govender ${ }^{4}$, DrT Govender ${ }^{4}$, Dr L Hellstrom4,

$\operatorname{Dr} L$ Holding $^{4}$, Dr I Katz ${ }^{14}$, Dr S Kibe $e^{14}$, Dr J Kumari ${ }^{15}$, Prof U Kyricos ${ }^{12}$, Ms. A Mentor ${ }^{16}$, Dr L Lotter ${ }^{17}$, Dr C Marx ${ }^{4}$, Prof M

McCulloch ${ }^{18}$, Dr J Morgan ${ }^{4}$, Dr N Matsiliza 4 , Dr M Meiring ${ }^{13}$, Miss P Mkhize ${ }^{19}$, Dr O Modupe ${ }^{20}$, Dr G Moonsamy ${ }^{21}$, DrT Motsohi ${ }^{8}$, Prof MR Moosa ${ }^{22}$, Mr J Mwangi'2, Prof S Naicker ${ }^{23}$, DrT Nupen ${ }^{13}$, Dr Shannon Odell', Prof G Paget ${ }^{24}$, Miss F Phelanyane ${ }^{8}$, Dr M Pretorius ${ }^{4}$, Dr J Rajbaran ${ }^{17}$, Dr L Spies ${ }^{4}$, Dr P Stead ${ }^{25}$, Mrs Aletta Stubbs ${ }^{26}$, Prof I van Biljonn ${ }^{27}$, DrV Rekhviashvili24,

Dr M van Jaarsveld ${ }^{4}$, Dr MVenter ${ }^{4}$, Dr SVenter ${ }^{28}$, Dr A Vermeulen ${ }^{29}$, Dr L Walker ${ }^{4}$, Mrs KWhite ${ }^{10}$, Dr JWiles ${ }^{13}$

'Division of Nephrology and Hypertension, Groote Schuur Hospital, Nephrology and Hypertension Research Unit, University of Cape Town; ${ }^{2}$ Palliative Medicine, Division of Family Medicine, University of Cape Town and Groote Schuur Hospital; ${ }^{3}$ Calvary Healthcare and St George Hospital, Sydney, Australia; ${ }^{4}$ Association of Palliative Care Practitioners of South Africa (PalPrac); ${ }^{5}$ Division of Nephrology, Department of Medicine, Robert Mangaliso Sobukwe Hospital, Kimberley; ${ }^{\circ}$ Division of Clinical Pharmacology, Groote Schuur Hospital, University of Cape Town; ${ }^{7}$ Division of Nephrology, Tygerberg Hospital and Stellenbosch University, Cape Town; ${ }^{8}$ School of Public Health and Family Medicine, University of Cape Town; ${ }^{9}$ Medical Management, Groote Schuur Hospital, Cape Town; ${ }^{10}$ Renal Unit, Livingstone Tertiary Hospital and Division of Nephrology and Hypertension, Nephrology and Hypertension Research Unit, University of Cape Town; "Emergency Medicine, Mitchells Plain Hospital; ' ${ }^{2}$ Department of Nursing, University of Cape Town; ${ }^{13}$ PaedsPal Paediatric Palliative Care; ${ }^{14}$ Department of Renal Medicine, St George Hospital, University of New South Wales, Sydney, Australia; ${ }^{15}$ Department of Health, Western Cape Government; ${ }^{16}$ Department of Social Work, Groote Schuur Hospital, Cape Town; ${ }^{17}$ Paarl Hospital; ${ }^{8}$ Department of Nephrology, Red Cross Children's Hospital, Cape Town; ${ }^{19}$ Life Healthcare; ${ }^{20}$ Council for Medical Schemes, South Africa; ${ }^{21}$ Charlotte Maxeke Johannesburg Academic Hospital, University of the Witwatersrand, Johannesburg; ${ }^{22}$ Department of Medicine, Tygerberg Hospital and Stellenbosch University, Cape Town; ${ }^{23}$ Department of Internal Medicine, University of the Witwatersrand, Johannesburg; ${ }^{24}$ Donald Gordon Medical Centre, University of the Witwatersrand, Johannesburg; ${ }^{25}$ Vincent Pallotti Hospital, Cape Town; ${ }^{26}$ Division of Nursing and Midwifery, University of Cape Town; ${ }^{27}$ Division of Paediatric Nephrology, Steve Biko Academic Hospital, Pretoria; ${ }^{28}$ Sungardens Hospice, Pretoria; ${ }^{29}$ George Provincial Hospital.
\end{abstract}

\section{ABSTRACT}

In South Africa, there is a high burden of end-stage kidney disease (ESKD). This is due to the burgeoning epidemics of communicable diseases like HIVIAIDS and non-communicable diseases, particularly hypertension and diabetes mellitus. One of the most difficult situations encountered by healthcare professionals dealing with patients with ESKD in South Africa is the management of a conservative or palliative care pathway for the many patients who have no other option. Patients with advanced chronic kidney disease (CKD) have a high burden of physical and psychosocial symptoms, poor outcomes and high costs of care. Many patients are managed in primary healthcare settings and either do not have access to palliative care or are not referred appropriately.

Renal supportive and palliative care involves a multidisciplinary approach to managing patients with ESKD, to ensure that symptoms are managed optimally and to provide support during advanced disease. It aims to improve quality of life for patients and their families and must be provided alongside curative medical care. This support should include those unable to gain access to life-saving dialysis and it should also provide care for patients where dialysis is not the best option.

The aim of this consensus statement is to assist healthcare providers to improve the management of symptoms and biopsychosocial factors of patients with ESKD in a South African context. The document was compiled through consensus building among healthcare professionals across South Africa. The professionals represented included nephrologists, palliative care physicians, social workers, nurses, paediatricians and hospital managers. We wish to acknowledge the contribution of Dr Frank Brennan, a leading expert in renal palliative and supportive care, who assisted greatly in the compilation of this document.

Keywords: palliative care; supportive care; end-stage kidney disease; South Africa.

Received 0 I April 2020; published II May 2020. 


\section{CONTENTS}

Background

Initiation of renal replacement therapy

Symptom management in end-stage kidney disease (ESKD)

- Validated scoring tools

- Table I. Management of common symptoms of advanced chronic kidney disease (CKD)

\section{Communication and advance care planning}

- Essential communication with patients and families with ESKD

- Advance healthcare planning

\section{Preserving renal function and managing complications of renal failure}

- Table 2. Classification of CKD

- Table 2. Strategies to preserve residual renal function and manage complications of CKD

\section{End-of-life care in ESKD}

\section{Service provision and collaborative care}

- The current challenges to providing an integrated renal supportive care/palliative care service

- Critical elements of creating a renal supportive clinic

- Table 3. Possible recommendations for creating a renal supportive care clinic

\section{Special considerations in paediatric patients}

- Decision making around renal replacement therapy

- Management options for children with ESKD

- The choice of treatment modality

- Suitability for renal replacement therapy

- Renal transplantation

- The role of paediatric palliative care in paediatric renal supportive care

- Where consultation may be required with specialty palliative care during renal supportive care

- Specific paediatric requirements for symptom management

Renal supportive care primary palliative care skills for nephrology teams: a recommended model

\section{Conclusions}

- Proposed research agenda

- Recommendations

\section{References}

\section{Addenda}

- Addendum I: Charlson Comorbidity Index

- Addendum 2: Karnofsky Performance Scale

- Addendum 3: IPOS-Renal

- Addendum 4: Useful online resources 


\section{BACKGROUND}

The incidence of end-stage kidney disease (ESKD) is increasing worldwide. In South Africa, the high degree of ESKD is due to burgeoning epidemics of communicable (such as HIVIAIDS) and non-communicable diseases, particularly hypertension and diabetes mellitus. However, the access to life-saving dialysis and transplantation is severely limited in the public health sector. Palliative and renal supportive care (RSC) aims to relieve the suffering of patients and families. Although we are unable to dialyse all patients, we can advocate that all patients receive equitable and comprehensive renal supportive and palliative care (RSCl PC). This care must be provided alongside treatment that may be curative and must not only be initiated at the very end of a patient's life [I]. In some cases, it may need to occur at the time of diagnosis, for example in the case of children with multi-organ involvement.

The aim of this document is to improve the care of all patients with ESKD whether receiving renal replacement therapy (RRT) or not, by integrating nephrology care, palliative care and family practice. It aims to align with the fundamental principles of Universal Health Coverage $(\mathrm{UHC})[2]$ and has the secondary goal of creating awareness regarding an alternative conservative management pathway, where appropriate. It has been written by a multiprofessional team in the hope that it will encourage multidisciplinary care and is intended for use by healthcare professionals in primary care, internal medicine and nephrology in South Africa.

This document was compiled through consensus building among healthcare professionals across South Africa. On II June 2019, 60 participants conducted a workshop in Cape Town to define and make recommendations on the main concerns and needs of ESKD patients. The professionals represented included nephrologists, palliative care physicians, social workers, nurses, paediatricians and hospital managers from across the country. The workshop also hosted Dr Frank Brennan, a leading expert in renal palliative and supportive care. He is renowned internationally, for his work on human rights in health care.

\section{INITIATION OF RENAL REPLACEMENT THERAPY}

"Provision of dialysis should benefit the patient, and not just prolong life" [3].

In South Africa, there are substantial limitations to accessing chronic dialysis [4]. Treatment options are limited in the public sector. Many patients, therefore, are on a conservative pathway, not through choice or medical recommendation, but through circumstance. However, regard- less of dialysis availability, healthcare professionals should address the patient's personal goals and aims for the future.

\section{Understanding and communicating prognosis}

The ability to prognosticate and communicate prognosis is essential [5]. This may be a long process and require frequent repeating. There are a few studies that combine prognostic factors in clinically useful prediction tools $[6,7]$.

\section{Patient-centred decision making}

In ideal circumstances, patient-centred decision making should be implemented by a multidisciplinary team $[8,9]$. It should be a family orientated and culturally appropriate process where the team and patient agree on a specific course of action based on a common understanding of the patient's treatment goals. It should consider the benefits and harms of the treatment and the likely outcomes. All the possible options should be discussed openly. This should include all dialysis modalities, withholding or withdrawing dialysis and an "opt-out" option for the patient in the future after a trial of dialysis. Access to private medical insurance should also be discussed.

The timing of the decision-making process is important. The Supportive and Palliative Care Indicators Tool (SPICT) $[10,1 \mid]$ advises that these discussions should be held at or when:

- Stage 4 or 5 chronic kidney disease (CKD) (estimated glomerular filtration rate $(e G F R)<30 \mathrm{~mL} / \mathrm{min} / \mathrm{m}^{2}$ ) with deteriorating health

- There is also strong evidence for using the Kidney Failure Risk Equation (KFRE) to better determine progression to ESKD (kidneyfailurerisk.com) [12]

- Kidney failure complicates other life-limiting conditions or treatment

- Ceasing or changing dialysis modality.

Periodic review of the proposed decision should be included in the plan. The timing of these reviews should be agreed on at the initial interview. The review should include whether dialysis is still benefiting the patient's personal aims or goals and should be revised after any new critical event (e.g. after a stroke).

The Renal Physicians Association of America suggests that it is reasonable to consider forgoing (not starting or ceasing) dialysis for the following groups of patients [13]:

- There is a condition precluding the technical process of dialysis (e.g. an uncooperative patient with advanced dementia) or the patient is medically unstable (e.g. suffers from profound hypotension).

- A terminal non-renal illness (we acknowledge that some may perceive benefit and choose to undergo dialysis). 
- Refusal/discontinuation of dialysis in a patient with decision-making capacity, who is fully informed and making a voluntary choice.

- Patients who no longer possess decision-making capacity and who have previously indicated refusal of dialysis in an advanced care directive, or those whose legal agents/surrogates refuse dialysis or request that it be discontinued.

- Patients with irreversible, profound neurological impairment.

- In the case of children, it may also be appropriate to withhold renal replacement if the family situation is unable to support the child (see paediatric section for more details).

- Patients over the age of 75 years, who have two or more of the following poor prognostic criteria:

- Depend on others for care due to increasing physical and/or emotional and/or mental health problems

- Significant weight loss (> 10\%).

- High comorbidity score, e.g. modified Charlson Comorbidity Index score of 8 or greater [14] (see Addendum ().

- Significantly impaired functional status, such as Karnofsky score $<40$ with limited reversibility [15] (see Addendum 2).

- The patient asks for palliative care, or chooses to reduce, stop or have no treatment.

\section{SYMPTOM MANAGEMENT IN ESKD}

Patients with advanced CKD experience multiple symptoms that contribute to their disease burden [16]. These guidelines are compiled to assist healthcare providers in managing patients with symptoms associated with advanced CKD.

\section{Validated scoring tools}

The routine screening of physical and emotional symptoms is recommended at each consultation using a validated tool. Recommended tools include:

I) Integrated Palliative Care Renal Outcome Scale-Renal (IPOS-Renal) [17-19] (see Addendum 3).

2) ESAS-r (Edmonton Symptom Assessment Systemrevised: Renal) [20] (see Addendum 4).

3) Brief Pain Inventory [2।] (see addendum 4).

The causes of a patient's symptoms other than the kidney disease should always be considered. Table I describes approach, utilizing medicines that are predominantly on the Essential Medicines List (EML). Adjusting the dose for renal function is important. The golden rule is start low and go slow, with frequent reassessment.

\section{COMMUNICATION AND ADVANCE CARE PLANNING}

\section{Essential communication with patients and families with ESIKD}

Compassionate and effective communication is key to developing a working and trustful relationship between patients, families and healthcare professionals. It requires knowledge about what, with whom and when difficult conversations should be had. A positive, non-judgmental attitude should be maintained. These skills can be taught and should be practised. Protocols such as SPIKES (breaking bad news) and the "Serious IInness Conversations" are examples of evidenced-based approaches to communication [36,37,39]. All breaking bad news conversations, especially around withholding or withdrawing dialysis, should be managed by a senior doctor on the team.

One of the most difficult challenges is the discussion with a patient in the public sector who cannot be offered dialysis. It is essential that everybody gives the same message when communicating with patients and families in order not to create false hope or distrust. All difficult conversations should be clearly documented in the patient notes. Such conversations should always be followed by reflection and, if necessary, debriefing. The moral distress of doctors involved in withdrawing or withholding dialysis requires collegial support from managers and other healthcare providers.

There are many barriers to having essential conversations with patients and families. Patient and/or family may misunderstand the diagnosis and prognosis, there may be cultural differences, clinician attitudes and beliefs around palliative care, lack of training and shortage of time available for difficult conversations. These conversations should aim to manage conflict, to acknowledge and address all emotions, to improve prognostic awareness and align care with expectations of patients and families.

The following are recommended essential conversations that should take place between healthcare professionals, patients and families:

a. Breaking Bad News [38] - must offer a hopeful, achievable alternative with a carefully considered palliative care plan

b. Serious IIIness Conversation [39]. 


\section{Advance Healthcare Planning}

Advance Healthcare Planning includes discussions with individuals about their preferences and wishes. They are best held when patients are relatively well, able to communicate effectively and have the mental capacity to make independent decisions. They should address values, goals and outcomes that are important to patients and families. The conversation should be ongoing and not a single event with the possibility of review if circumstances change. The plan will assist the healthcare team to make treatment recommendations that are aligned with specified values. This becomes increasingly important when the patient is no longer able to make or verbalise decisions independently. Research shows that patients expect

Table I. Management of common symptoms of advanced CKD [16,22].

\begin{tabular}{|c|c|c|c|c|}
\hline \multirow[t]{2}{*}{ Symptom } & \multirow[t]{2}{*}{ Prevalence } & \multirow[t]{2}{*}{ Likely causes } & \multicolumn{2}{|l|}{ Management } \\
\hline & & & Non-pharmacological & $\begin{array}{l}\text { Pharmacological } \\
\text { (stepwise approach) }\end{array}$ \\
\hline \multirow{7}{*}{$\begin{array}{l}\text { Nausea, } \\
\text { vomiting, bitter } \\
\text { taste and } \\
\text { anorexia [16] }\end{array}$} & \multirow{7}{*}{$\begin{array}{c}46 \% \\
(9-90 \%)\end{array}$} & \multirow{7}{*}{$\begin{array}{l}\text { Metabolic acidosis } \\
\text { Drugs (e.g. opiates) } \\
\text { Constipation } \\
\text { Delayed gastric } \\
\text { emptying } \\
\text { Uraemic toxins }\end{array}$} & \multirow{7}{*}{$\begin{array}{l}\text { Exclude offending drugs } \\
\text { Small, frequent meals } \\
\text { Avoid alcohol, greasy, spicy, sweet and } \\
\text { bitter-tasting food and drinks } \\
\text { Postprandial upright position } \\
\text { Complementary therapies (ginger, } \\
\text { relaxation, acupuncture, etc.) }\end{array}$} & \multirow{6}{*}{$\begin{array}{l}\text { - Metoclopramide (low dose) 5-10 mg } \\
\text { tds (oral, SC or IM) half-an-hour before } \\
\text { meals. Start with } 5 \mathrm{mg} \text { tds and titrate to } \\
\text { maximal dose of } 10 \mathrm{mg} \text { tds [23] } \\
\text { - Haloperidol } 0.5-1.5 \mathrm{mg} / 24 \mathrm{~h} \mathrm{CSCl/PO/} \\
\text { SC initiation dose. Max dose } 5 \mathrm{mg} / 24 \mathrm{~h} \text {. } \\
\text { For occasional use dose unchanged, for } \\
\text { regular use half the dose [23] }\end{array}$} \\
\hline & & & & \\
\hline & & & & \\
\hline & & & & \\
\hline & & & & \\
\hline & & & & \\
\hline & & & & $\begin{array}{l}\text { Recommended but not on the EDL } \\
\text { - } \text { Ondansetron } 4-8 \mathrm{mg} \text { tds (oral or SC/ } \\
\text { IV) (caution: very constipating) }\end{array}$ \\
\hline \multirow[t]{6}{*}{ Constipation } & \multirow[t]{6}{*}{$8-65 \%$} & \multirow{2}{*}{$\begin{array}{l}\text { Phosphate binders } \\
\text { (calcium carbonate) }\end{array}$} & \multirow{6}{*}{$\begin{array}{l}\text { Mild exercise } \\
\text { Bulking agents like fibre are not } \\
\text { recommended for patients using } \\
\text { constipating medication or with decreased } \\
\text { fluid/food intake or decreased activity }\end{array}$} & - Lactulose syrup I5 mL po (daily, can \\
\hline & & & & increase to bd) \\
\hline & & Oral iron & & - Liquid paraffin \\
\hline & & Ondansetron & & - Senokot 2 tab po nocte \\
\hline & & Fluid restriction & & - Dulcolax (bisacodyl) 5-20 mg po nocte \\
\hline & & & & - Fleet enema PR (if constipation severe) \\
\hline \multirow{7}{*}{$\begin{array}{l}\text { Depression } \\
\text { and anxiety } \\
{[16,24-29]}\end{array}$} & \multirow[t]{7}{*}{$25-40 \%$} & \multirow{7}{*}{$\begin{array}{l}\text { It is normal to feel } \\
\text { sad when diagnosed } \\
\text { with a life-threatening } \\
\text { illness. However, } \\
\text { when low mood is } \\
\text { constant, depression } \\
\text { needs to be } \\
\text { excluded. }\end{array}$} & \multirow{7}{*}{$\begin{array}{l}\text { Manage distressing symptoms: psycho- } \\
\text { social and spiritual factors that can } \\
\text { contribute to anxiety and low mood. } \\
\text { Patient and family education and support. } \\
\text { Support groups or encourage support } \\
\text { from family, peer groups, religious leaders } \\
\text { and friends. } \\
\text { In the case of children, attempt to get the } \\
\text { patient to school even if for short periods. } \\
\text { Exercise improves mood and anxiety in } \\
\text { CKD patients. } \\
\text { Involvement of occupational therapist, } \\
\text { social worker and psychologist/psychiatrist } \\
\text { - Cognitive behavioural therapy }\end{array}$} & - Citalopram 5-10 mg daily \\
\hline & & & & - Fluoxetine 10-20 mg daily \\
\hline & & & & - Sertraline 25 mg mane \\
\hline & & & & - Amitriptyline 10 mg nocte may also \\
\hline & & & & $\begin{array}{l}\text { assist with sleep disturbance (titrate } \\
\text { according to response up to } 25 \text { mg) }\end{array}$ \\
\hline & & & & $\begin{array}{l}\text { - Lorazepam } 0.5-1.0 \mathrm{mg} \text { sublingual or } \\
\text { orally may be used for short-term relief } \\
\text { of anxiety }\end{array}$ \\
\hline & & & & \\
\hline \multirow{8}{*}{$\begin{array}{l}\text { Uraemic } \\
\text { pruritis [16] }\end{array}$} & \multirow{8}{*}{$\begin{array}{c}41 \% \\
(24 \% \text { severe) }\end{array}$} & \multirow{8}{*}{$\begin{array}{l}\text { Exacerbating factors: } \\
\text { Non-dermatological } \\
\text { Anaemia } \\
\text { Iron deficiency } \\
\text { Dermatological } \\
\text { Xerosis } \\
\text { Drug related } \\
\text { Contact dermatitis } \\
\text { Infestation }\end{array}$} & \multirow{8}{*}{$\begin{array}{l}\text { Appropriate skin care } \\
\text { Bath in lukewarm water and use } \\
\text { fragrance-free soap } \\
\text { Pat dry } \\
\text { Moisturize with aqueous emollients }\end{array}$} & - Antihistamines have a very limited role. \\
\hline & & & & $\begin{array}{l}\text { - "Pregabalin 25-75 mg (initiate at } \\
25 \text { mg nocte and titrate up slowly. ESKD }\end{array}$ \\
\hline & & & & on a conservative pathway, 25 mg on \\
\hline & & & & 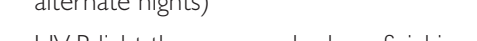 \\
\hline & & & & $\begin{array}{l}\text { - UV-B light therapy may be beneficial in } \\
\text { patients with refractory symptoms (may } \\
\text { only be offered in tertiary centres) }\end{array}$ \\
\hline & & & & $\begin{array}{l}\text { - Patients on dialysis: dialysis adequacy and } \\
\text { calcium and phosphate balance should } \\
\text { be addressed }\end{array}$ \\
\hline & & & & $\begin{array}{l}\text { Recommended but not on the EDL } \\
\text { - Capsaicin cream } 0.025 \%\end{array}$ \\
\hline & & & & $\begin{array}{l}\text { - "Gabapentin 100-200 mg nocte (initiate } \\
\text { I00 mg nocte alternate days and titrate } \\
\text { up slowly. If the patient is on dialysis this } \\
\text { should be given after dialysis) }\end{array}$ \\
\hline
\end{tabular}


Table I (continued). Management of common symptoms of advanced CKD [16,22].

\begin{tabular}{|c|c|c|c|c|}
\hline \multirow[t]{2}{*}{ Symptom } & \multirow[t]{2}{*}{ Prevalence } & \multirow[t]{2}{*}{ Likely causes } & \multicolumn{2}{|l|}{ Management } \\
\hline & & & Non-pharmacological & $\begin{array}{l}\text { Pharmacological } \\
\text { (stepwise approach) }\end{array}$ \\
\hline \multirow[t]{8}{*}{$\begin{array}{l}\text { Pain [18,30-32] } \\
\text { No studies on } \\
\text { long-term use } \\
\text { of any analgesics } \\
\text { in CKD }\end{array}$} & \multirow[t]{8}{*}{$58 \%$} & $\begin{array}{l}\text { Determine cause: } \\
\text { Exclude } \\
\text { rheumatological: gout, } \\
\text { rheumatoid arthritis, } \\
\text { osteoarthritis }\end{array}$ & \multirow[t]{8}{*}{$\begin{array}{l}\text { - Behavioural therapy: cognitive } \\
\text { behavioural therapy, relaxation therapy }\end{array}$} & \multirow[t]{2}{*}{$\begin{array}{l}\text { - If there is an identified pain syndrome } \\
\text { (e.g. OA, diabetic peripheral neuropathy, } \\
\text { cancer, gout) treat according to } \\
\text { guidelines for that syndrome for the } \\
\text { general population, adjusting medication } \\
\text { according to eGFR }\end{array}$} \\
\hline & & \multirow[t]{7}{*}{ Steal syndrome } & & \\
\hline & & & & - Topical anti-inflammatories if joint pain \\
\hline & & & & - Paracetamol (max 3 g dly) [33] \\
\hline & & & & $\begin{array}{l}\text { - Tramadol or oxycodone (tramadol } \\
50 \mathrm{mg} \text { bd or oxycodone 5-20 mg tds) } \\
\text { titrate up slowly (*oxycodone is not on } \\
\text { the EDL) }\end{array}$ \\
\hline & & & & $\begin{array}{l}\text { - Morphine: generally, not recommended, } \\
\text { as metabolites are renally excreted and, } \\
\text { in normal doses, will cause toxicity. If } \\
\text { used, should be used with significant } \\
\text { caution. Advised for moderate to } \\
\text { severe pain syndromes. Start with I-2.5 } \\
\text { mg PO/SC prn and titrate to affect. If } \\
\text { pain is stable, consider switching to a } \\
\text { transdermal fentanyl patch [23] }\end{array}$ \\
\hline & & & & $\begin{array}{l}\text { Recommended but not on the EDL } \\
\text { - "Transcutaneous patches: (only use when } \\
\text { pain is stable) }\end{array}$ \\
\hline & & & & $\begin{array}{l}\text { - fentanyl I2.5, } 25 \mu \mathrm{g} \\
\text { - buprenorphine } 5 \mu \mathrm{g}\end{array}$ \\
\hline \multirow[t]{4}{*}{$\begin{array}{l}\text { Neuropathic } \\
\text { pain }\end{array}$} & & & \multirow[t]{4}{*}{ Same as pain above } & $\begin{array}{l}\text { - "Pregabalin } 25-75 \text { mg (initiate at } \\
25 \text { mg nocte and titrate up slowly. ESKD } \\
\text { on a conservative pathway, } 25 \text { mg on } \\
\text { alternate nights) }\end{array}$ \\
\hline & & & & $\begin{array}{l}\text { - Amitriptyline } 10 \mathrm{mg} \text { nocte may also be } \\
\text { effective, assisting with both neuropathic } \\
\text { pain and sleep disturbance (may titrate } \\
\text { according to response up to } 25 \mathrm{mg} \text { ) }\end{array}$ \\
\hline & & & & $\begin{array}{l}\text { - Add opioids (as in section above): } \\
\text { stepwise process if moderate to severe } \\
\text { pain in titrated doses. }\end{array}$ \\
\hline & & & & $\begin{array}{l}\text { Recommended but not on the EDL } \\
\text { - "Gabapentin 100-200 mg nocte (initiate } \\
\text { I00 mg nocte alternate days and titrate } \\
\text { up slowly. If the patient is on dialysis, this } \\
\text { should be given after dialysis) }\end{array}$ \\
\hline \multirow{10}{*}{$\begin{array}{l}\text { Sleep } \\
\text { disturbances [16] }\end{array}$} & \multirow{10}{*}{$\begin{array}{c}60.1 \% \\
(54.9-83.1 \%)\end{array}$} & Anaemia: see Table 2 & - Exercise & \multirow{2}{*}{$\begin{array}{l}\text { - Take a detailed sleep history and treat } \\
\text { if able }\end{array}$} \\
\hline & & Vitamin D deficiency & - Psychosocial and spiritual support & \\
\hline & & Metabolic acidosis & \multirow{3}{*}{$\begin{array}{l}\text { - Cognitive and psychological therapies, } \\
\text { e.g. relaxation therapy, meditation } \\
\text { - Optimize sleep hygiene (no stimulants, } \\
\text { reserve bedroom for sleep) }\end{array}$} & $\begin{array}{l}\text { - Manage restless leg syndrome, pruritus, } \\
\text { pain and obstructive sleep apnoea }\end{array}$ \\
\hline & & hyperthyroidism & & - If pain present treat as above \\
\hline & & Adrenal insufficiency & & - Amitriptyline 10 mg nocte may also be \\
\hline & & Anxiety & \multirow{5}{*}{$\begin{array}{l}\text { - Complementary activities (acupuncture, } \\
\text { massage) }\end{array}$} & $\begin{array}{l}\text { effective, assisting with both neuropathic } \\
\text { pain and sleep disturbance (may titrate }\end{array}$ \\
\hline & & Depression & & according to response up to $25 \mathrm{mg}$ ) \\
\hline & & \multirow{3}{*}{$\begin{array}{l}\text { Medications: } \\
\text { benzodiazepines } \\
\text { antidepressants } \\
\text { opioids }\end{array}$} & & Drugs recommended but not on EDL \\
\hline & & & & $\begin{array}{l}\text { - "EPO if available (see KDIGO guidelines) } \\
\text { [34] }\end{array}$ \\
\hline & & & & $\begin{array}{l}\text { - Melatonin (if available) } 2 \text { mg po I-2 h } \\
\text { prior to sleep }\end{array}$ \\
\hline
\end{tabular}


Table I (continued). Management of common symptoms of advanced CKD [16,22].

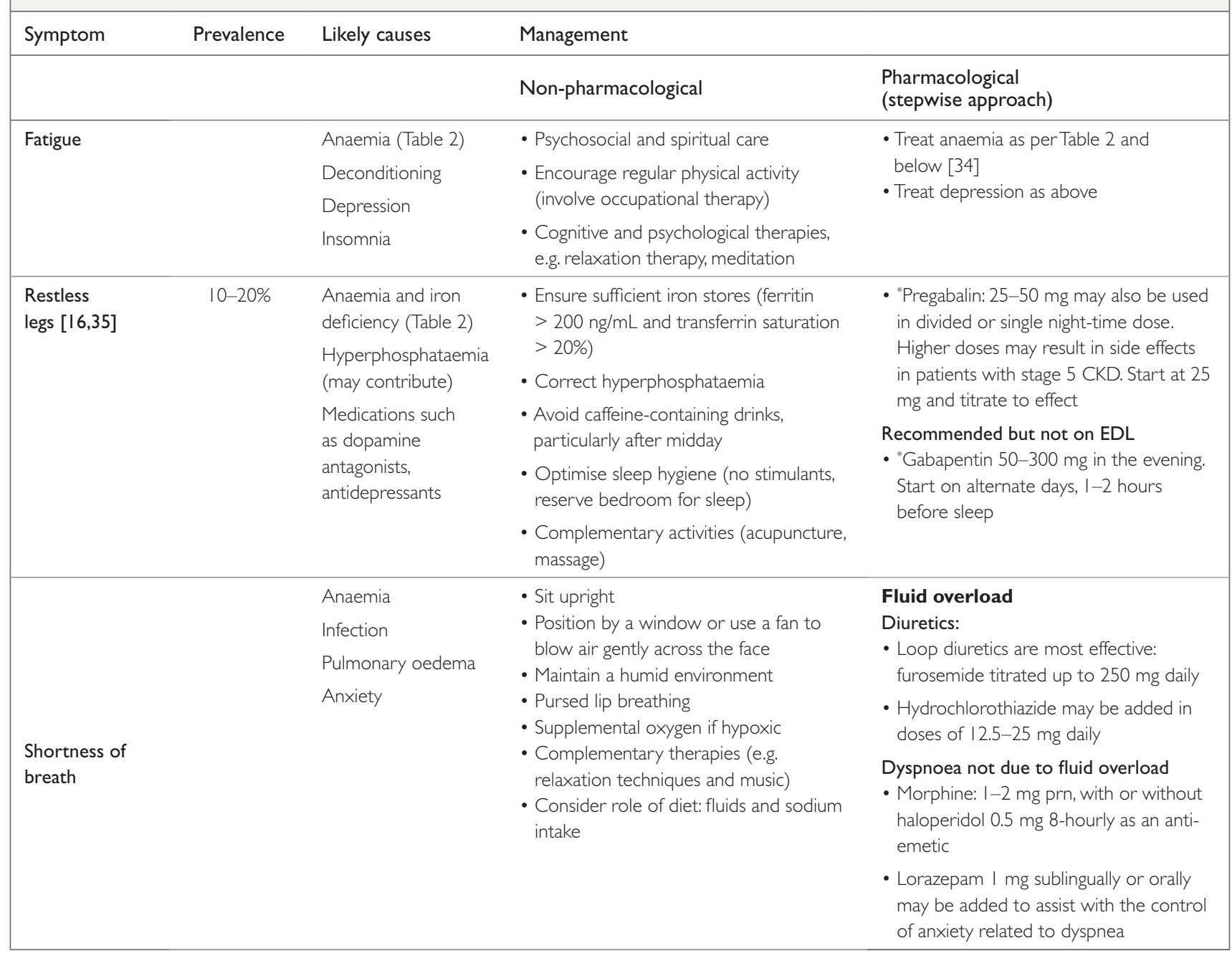

Abbreviations: mg, milligram; tds, three times daily; SC, subcutaneous; IM, intramuscular; PR, per rectum; h, hour; CBT, cognitive behavioural therapy; CSCl, continuous subcutaneous infusion; EDL, Essential Drugs List; eGFR, estimated glomerular filtration rate; po, per os; od, once daily; qid, six-hourly; IV, intravenous; mL, millilitres; UV-B, ultraviolet; EPO, erythropoietin; prn, as required.

"Drugs not available on the EDL or requiring initiation at a tertiary hospital.

clinicians to initiate these conversations, and when skilfully done it does not increase anxiety or hopelessness.

\section{Examples of how to start the conversation:}

- Routine visit: "It seems you are doing well but I like talking to all my patients about their preferences for care in case they get very sick."

- Episode of acute illness: "To make sure we are working together while you are sick, I would like to talk about your goals of care."

"I would like to talk to you about your current symptoms and how you would like us to manage it."

- Follow-up visit after an episode of acute illness: "What would be your goals of care if this happens again?"

\section{Topics to discuss:}

- Substitute decision makers or patient advocates: "Who
- Understanding of current illness

- Current symptoms, fears and expectations

- How WE are going to address them

- What are you hoping for?

- Hope for the best but plan for the worst

- What have you learned from previous experiences about how you want to be cared for? (explore sources and clarify misconceptions)

- Support systems

- Make sure values, goals and care plan are communicated with decision makers and all decision makers are comfortable with the decisions.

- All communication should be clearly documented and included in the patient notes [38].

See Addendum 4 for the link to the Hospice Palliative Care Association of South Africa (HPCA) Advance Health Care Planning document. 


\section{PRESERVING RENAL FUNCTION AND MANAGING COMPLICATIONS OF RENAL FAILURE}

Screening for CKD must be conducted in high risk individuals at each interaction with the healthcare system. High risk individuals in South Africa include those with:

- Diabetes

- Hypertension

- Urological disorders

- Family history of renal disease

- Drug addicts ("tik”, cocaine)

- HIV-positive individuals.

The guidelines that follow are specifically aimed at CKD stages 4 and 5 (Figure I). Table 2 describes management strategies to preserve residual renal function and manage complications of CKD.

\section{END-OF-LIFE CARE IN END-STAGE KIDNEY DISEASE}

Ethical and compassionate care is the main goal when managing a patient at the end of life. This period can be defined as a "period of irreversible functional decline prior to death" [49]. Care plans need to be adjusted to allow patients to have a "good death", where distressing symp- toms and suffering are treated competently and compassionately. The ethical framework that underpins endof-life care [49] includes:

- Maintain open communication with the patient and the family

- Provide adequate relief of pain and other symptoms

- Ensure continuity of care of the patient

- Do not subject a dying patient to futile treatment that can increase distress

- Provide integrated bio-psychosocial and spiritual care

- Families should be actively supported during this time and during their bereavement.

Common signs and symptoms of a dying patient [49]:

- Weight loss

- Profound weakness and fatigue

- Social withdrawal

- Not eating

- Delirium, confusion or drowsiness

- Difficulty in swallowing

- Severe dyspnoea

- Decreased or no urine output

- Anasarca

- Cool skin.

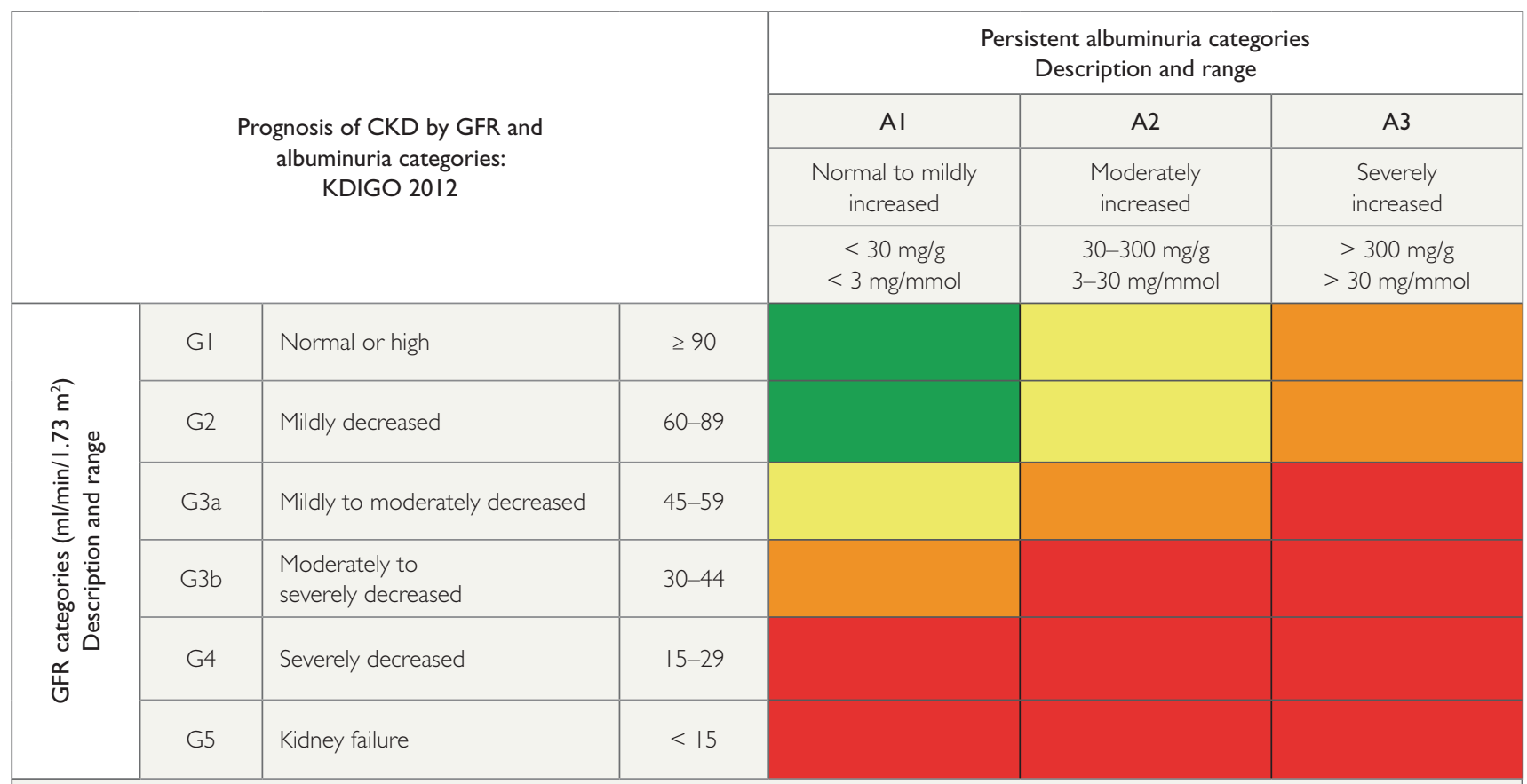

Figure I. Classification of chronic kidney disease by GFR and degree of albuminuria. Patients at low or moderate risk for disease progression (green/yellow) should be followed up at least yearly, those at high risk (orange) twice-yearly, and those at very high risk (red) should be seen three or more times per year, as required. Reproduced with permission from KDIGO [40,4I]. Abbreviations: CKD, chronic kidney disease; GFR, glomerular filtration rate; KDIGO, Kidney Disease: Improving Global Outcomes. 
Table 2. Strategies to preserve residual renal function and manage complications of stages 4 and 5 CKD [22].

\begin{tabular}{|c|c|c|c|}
\hline & Aim/target of treatment & Non-pharmacological & Pharmacological \\
\hline $\begin{array}{l}\text { General measure: } \\
\text { Lifestyle }\end{array}$ & $\begin{array}{l}\text { Aim: to balance preservation } \\
\text { of residual renal function while } \\
\text { maintaining } \mathrm{QOL}\end{array}$ & $\begin{array}{l}\text { - Avoid and manage obesity } \\
\text { - Avoid smoking } \\
\text { - Salt restriction } \\
\text { - Implementation of healthy lifestyles } \\
\text { - Early identification and treatment of } \\
\text { urinary tract infections } \\
\text { - Education of patients on potentially } \\
\text { nephrotoxic agents }\end{array}$ & $\begin{array}{l}\text { - Avoid over-the-counter medications/ } \\
\text { illicit substance use/traditional } \\
\text { medications } \\
\text { - Avoid nonsteroidal anti-inflammatory } \\
\text { drugs. } \\
\text { - Ensure HIV is virally suppressed with } \\
\text { ART (avoid TDF) } \\
\text { - Avoid/temporarily discontinue ACEIs/ } \\
\text { ARBs if dehydrated }\end{array}$ \\
\hline $\begin{array}{l}\text { BP (recommend } \\
\text { review of the } \\
\text { SA hypertension } \\
\text { guideline) [42] }\end{array}$ & $\begin{array}{l}\text { Aim: to optimise } Q O L \text {, preserve } \\
\text { physical and cognitive function and } \\
\text { minimise the risk of orthostatic } \\
\text { hypotension }[22] \\
\text { BP target } \pm 160 / 90 \mathrm{mmHg}\end{array}$ & $\begin{array}{l}\text { - Salt restriction } \\
\text { - Fluid restriction } \\
\text { - Complementary therapies } \\
\text { (e.g. relaxation techniques and music) }\end{array}$ & $\begin{array}{l}\text { Furosemide titrated to effect (titrate to } \\
250 \mathrm{mg} \text { bd) } \\
\text { Avoid } \mathrm{K}^{+} \text {sparing agents if potassium } \\
\text { is }>5.6 \mathrm{mmol} / \mathrm{L} \text {, i.e. (ACEi/ARB/ } \\
\text { spironolactone) unless regular 3-monthly } \\
\text { blood tests can be done }\end{array}$ \\
\hline Fluid & $\begin{array}{l}\text { Aim: avoid excessive intake and } \\
\text { promote euvolemia }\end{array}$ & $\begin{array}{l}\text { - Consider role of diet: fluids and sodium } \\
\text { intake } \\
\text { - Avoid table salt and cooking with salt } \\
\text { - Avoid salt-containing spices and } \\
\text { seasoning } \\
\text { - Consider alternative flavouring agents - } \\
\text { unsalted herbs, garlic, ginger, chillies } \\
\text { - Avoid processed and canned foods }\end{array}$ & $\begin{array}{l}\text { Diuretics (if not anuric): } \\
\text { - Loop diuretics are most effective: } \\
\text { furosemide titrated up to } 250 \mathrm{mg} \text { daily } \\
\text { - If short of breath, see Table I }\end{array}$ \\
\hline Acidosis & $\begin{array}{l}\text { Prevent symptoms associated with } \\
\text { acidosis: } \mathrm{SOB} \text {, nausea, mineral bone } \\
\text { disease (MBD), appetite }\end{array}$ & & $\begin{array}{l}\text { Severe acidosis: } \\
\text { - Treat acidosis to maintain bicarbonate } \\
>23 \mathrm{mmol} / \mathrm{L} \text { and within upper limit } \\
\text { of normal range }[43,44] \text { (level of } \\
\text { evidence } 2 \mathrm{~B} \text { ) } \\
\text { - Starting dose: Citrosoda } 4 \mathrm{~g} \text {, sodium } \\
\text { bicarbonate ( } 1.5-2 \mathrm{~g} \text { ) or baking soda } \\
\text { 1/2 teaspoon dissolved in } 125 \mathrm{~mL} \\
\text { water }=26.8 \mathrm{mEq} \text { bicarbonate }\end{array}$ \\
\hline Hyperkalaemia & Aim: to avoid fatal arrhythmia & $\begin{array}{l}\text { - Avoid foods high in potassium (banana, } \\
\text { avocado, potatoes, tomatoes) }\end{array}$ & $\begin{array}{l}\text { - Avoid ACEi/ARB/spironolactone } \\
\text { - Consider sorbito//lactulose } \\
\text { - Add/increase diuretics }\end{array}$ \\
\hline $\begin{array}{l}\text { Anaemia management } \\
\text { See KDIGO } \\
\text { guideline [34] }\end{array}$ & $\begin{array}{l}\text { Aim: to preserve } \mathrm{QOL} \text { and avoid } \\
\text { symptomatic anaemia }\end{array}$ & $\begin{array}{l}\text { - Surveillance of } \mathrm{Hb} \text { and iron levels } \\
\text { - Exclude other causes of anaemia }\end{array}$ & $\begin{array}{l}\text { The overall aim is to treat symptomatic } \\
\text { anaemia } \\
\text { - Oral supplementation (e.g. iron } \\
\text { sulphate I50 mg po daily (can be } \\
\text { constipating)) } \\
\text { - Iron supplementation: examples include } \\
\text { Venofer /Rautevene/Zypiron/Cosmofer. } \\
\text { IV iron can be given as a max dose of } \\
200 \mathrm{mg} \text { IV stat or total dose infusions } \\
\text { of I000-2000 mg } \\
\text { - Targets for CKD patients include } \\
\text { transferrin saturation 20-30\%, and } \\
\text { ferritin }>300 \mathrm{ng} / \mathrm{mL} \\
\text { - Erythropoietin (EPO) supplementation: } \\
\text { only if the patient is symptomatic with } \\
\text { anaemia and only if available to the } \\
\text { patient } \\
\text { - Transfusions of packed red cells may be } \\
\text { necessary if the patient is symptomatic, } \\
\text { particularly if EPO is not available }\end{array}$ \\
\hline $\begin{array}{l}\text { Calcium and } \\
\text { phosphate metabolism: } \\
\text { See KDIGO } \\
\text { guideline [45] }\end{array}$ & $\begin{array}{l}\text { Aim: should not be to focus on } \\
\text { normalising biochemistry but } \\
\text { rather on emphasising adequate } \\
\text { nutrition }\end{array}$ & $\begin{array}{l}\text { Emphasize adequate nutrition (avoid } \\
\text { malnutrition) } \\
\text { Avoid high phosphate containing food } \\
\text { (dairy, nuts, legumes, etc.) } \\
\text { - Liberalize the diet }\end{array}$ & $\begin{array}{l}\text { - Continue vitamin D supplementation, } \\
\text { and phosphate binder if patient is } \\
\text { tolerating (and if predicted survival } \\
\text { is long) } \\
\text { - Vitamin D } 50000 \text { U weekly } \\
\text { - Calcium carbonate/acetate up to I } 500 \\
\text { mg total calcium per day - take with } \\
\text { meals (e.g. Titralac/chewable B-Cal/ } \\
\text { Glycal II tds with food) }\end{array}$ \\
\hline
\end{tabular}


Table 2 (continued). Strategies to preserve residual renal function and manage complications of stages 4 and 5 CKD [22].

\begin{tabular}{|c|c|c|c|}
\hline & Aim/target of treatment & Non-pharmacological & Pharmacological \\
\hline \multirow{3}{*}{$\begin{array}{l}\text { Diabetes } \\
\text { See South African } \\
\text { diabetes guidelines [46] }\end{array}$} & \multirow{2}{*}{$\begin{array}{l}\text { Aim: simplify medication regimens. } \\
\text { As CKD progresses, the need for } \\
\text { medications decreases. }\end{array}$} & - Limited fruit and fruit juices & - Stop metformin in advanced CKD \\
\hline & & - Healthy diabetic diet & \multirow{2}{*}{$\begin{array}{l}\text { - Titrate down insulin - as CKD } \\
\text { progresses, the need for insulin } \\
\text { decreases and requires patient } \\
\text { education and monitoring of blood } \\
\text { sugar levels }\end{array}$} \\
\hline & $\begin{array}{l}\text { Less stringent } \mathrm{HbA} I \mathrm{C} \text { targets } \\
(8 \%)\end{array}$ & & \\
\hline Lipid & $\begin{array}{l}\text { No evidence that statins } \\
\text { provide benefit in context of } \\
\text { significant frailty or decreased life } \\
\text { expectancy }[47,48]\end{array}$ & - Emphasize adequate nutrition & - Stop statin \\
\hline \multirow[t]{3}{*}{ Managing medication } & \multirow[t]{3}{*}{$\begin{array}{l}\text { Not causing harm and simplifying } \\
\text { medication regiments }\end{array}$} & & $\begin{array}{l}\text { - STOP ANY NON-ESSENTIAL } \\
\text { MEDICATION (e.g. simvastatin) }\end{array}$ \\
\hline & & & $\begin{array}{l}\text { - Stop medications contraindicated in } \\
\text { renal failure, e.g. metformin and digoxin }\end{array}$ \\
\hline & & & - Adjust drug dose for renal function \\
\hline
\end{tabular}

Abbreviations: HIV, human immunodeficiency virus; ART, antiretroviral therapy; TDF, tenofovir; QOL, quality of life; NSAID, non-steroidal anti-inflammatory drug; ACEi, angiotensin converting enzyme inhibitor; ARB, angiotensin receptor blocker; bd, twice daily; Hb, haemoglobin; BP, blood pressure.

\section{Essential care steps:}

- All members of the care team should communicate effectively with one another so that the advanced care plan, should there be one, is respected and instituted.

- All members of the care team should be adept at communicating compassionately with the patient and the family in order to break bad news and initiate discussions around withdrawing or withholding artificial nutrition, inappropriate hydration and medically inappropriate investigations or interventions.

- The patient's decision regarding place of death should be respected as far as possible.

- Medication management:

- Rationalise medications: stop those not contributing to improvement in quality of life.

- Prescribe medication to treat symptoms and anticipated problems.

- Use an effective route, especially if the patient cannot swallow, e.g. subcutaneous, intravenous or intramuscular.

- Nursing care should be focused on dignity and avoiding unnecessary nursing interventions.

- Family care:

- Families need to be compassionately informed about the prognosis and should be provided with information around the expected symptoms and management. Healthcare providers should be led by the families around the type and amount of information provided.

- Children need to be appropriately addressed with
- Prepare the patient's family and carers regarding bereavement, building resilience and practical aspects of handling the deceased's body and dealing with undertakers - all of which should be respectful of the patient's cultural and religious preferences.

- Spiritual care should be offered and provided to all patients and families.

- Support for healthcare professionals involved in caring for the deceased should be provided and include debriefing and building resilience.

- Auditing and reflection of this process would allow improvement in the managing of the dying patient with ESKD.

\section{SERVICE PROVISION AND COLLABORATIVE CARE}

\section{The ideal model for palliative care in CKD [I6]}

Healthcare utilisation in advanced CKD is high [50]. There are limited data on the cost-effectiveness of renal supportive care frameworks [5l]; however, there is more solid evidence for other illness, such as cancer [50]. Supportive care may reduce hospitalisations, intensive care admissions and emergency room visits and result in fewer deaths in acute care facilities [50]. Cost benefit also needs to be analysed in terms of personal cost. The burden experienced by families include physical, emotional, social, and economic dimensions. An integrated service from the start of dialysis until death and into bereavement to support families has been reported as an option to improve clinical care [52]. 

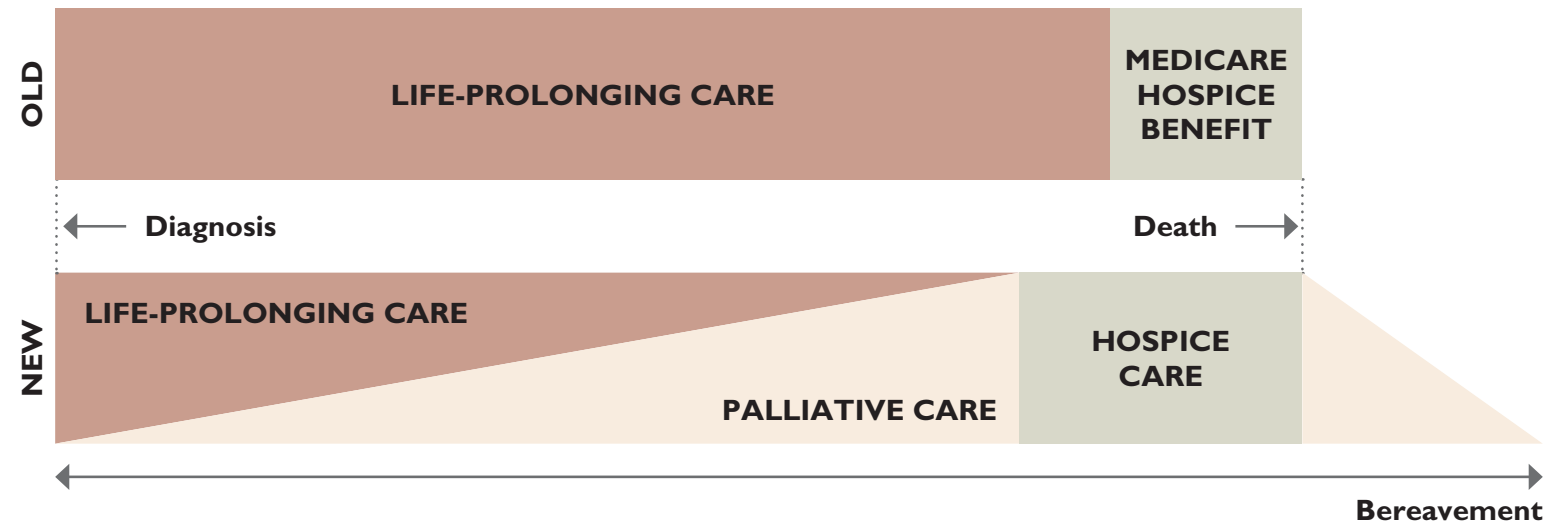

Source: Center to Advance Pallative Care

\section{Palliative care models}

The current challenges to providing an integrated RSC/ PC service include:

- Disparity of access to renal replacement therapy (RRT) in the public versus private sector

- Lack of integration of care between primary, secondary and tertiary facilities

- Limited palliative care teams and beds in both the private and public sectors

- Under-utilisation of home-based care and communityorientated primary care workers

- Unclear trajectory/prognosis of many patients with advanced CKD.

\section{Critical elements of creating a renal supportive clinic}

There are numerous aspects that need to be considered when creating an RSC/PC clinic. First, there needs to be strong collaboration between multiple disciplines, including the nephrologist, primary caregiver (GP), palliative care physician, social worker and nursing staff. Second, there needs to be awareness of all available palliative care options and support structures in both the private, public and NGO sectors. Third, resources need to be appropriately allocated at primary, secondary and tertiary care levels. This will require discussions with government, hospital management and medical insurance companies.

In a resource-limited setting, upskilling staff at all healthcare levels through education and exposure is essential. A multidisciplinary RSC/PC clinic would serve as a platform to expand training, create awareness and upskill across the care continuum. Establishment of this clinic could be done at a tertiary centre, with primary healthcare physicians rotating through this service and nephrologists supporting community health centres with outreach. Once a care plan is formulated, it should be continued at primary level care and community-based services (home-based carers) should be involved.

Improved communication is essential between all healthcare levels. This can be achieved with a simple booklet for patients (a roadmap), which would detail the advanced care plan (ACP) and current treatments. Electronic health platforms are also becoming increasingly common. Technology needs to be used by health professionals to link peripheral teams to the expertise of the multidisciplinary team. A call-in/Skype system could be used during the multidisciplinary clinic to support primary carers with advice on clinical management and symptoms. Web-based information is a cost-effective tool to assist families in providing care. It could offer information to connect family and relatives to resources and support structures in both the private, public and NGO sectors. A study showed that families caring for a dying patient required the following information: knowledge of the condition, information on medication, patient hygiene and nutritional care, contacts for emergency support and support options for the carer [53].

In a cost-constrained environment, the use of the whole team needs to be optimised, which in the South African setting includes home-based care, community nurses and may involve trained volunteers as a possible innovative solution. The literature also states that the presence and availability of nurses was found to be crucial for volunteers, 
Table 3. Possible recommendations for creating a renal supportive care clinic.

\begin{tabular}{|c|c|c|c|}
\hline Recommendations & Logistics & Advantages & Disadvantages \\
\hline Hospital passport & $\begin{array}{l}\text { - Information booklet kept by the } \\
\text { patient providing hospital staff with } \\
\text { vital information regarding: } \\
\text { - Diagnosis } \\
\text { - Advanced care directive } \\
\text { - Medication } \\
\text { - End-of-life plan }\end{array}$ & $\begin{array}{l}\text { - Improved integration of care } \\
\text { between different levels of heathcare } \\
\text { provision. } \\
\text { - Avoidance of unnecessary } \\
\text { investigations and admissions } \\
\text { - Ensure patient's end-of-life wishes } \\
\text { are respected }\end{array}$ & $\begin{array}{l}\text { - Needs resources to establish the } \\
\text { passport }\end{array}$ \\
\hline $\begin{array}{l}\text { Multidisciplinary team } \\
\text { at a primary care } \\
\text { centre }\end{array}$ & $\begin{array}{l}\text { - Staff: social worker, nursing staff and } \\
\text { primary healthcare doctor; access to } \\
\text { nephrologist, dietician and palliative } \\
\text { care trained physician } \\
\text { - Focused on counselling and linking } \\
\text { families with social/community } \\
\text { networks } \\
\text { - Symptom management } \\
\text { - Advanced Care Planning (uses } \\
\text { healthcare document retained by } \\
\text { the patient) }\end{array}$ & $\begin{array}{l}\text { - Upskilling available staff and } \\
\text { knowledge transfer } \\
\text { - Integrating existing resources } \\
\text { - Holistic continued care and support } \\
\text { to families } \\
\text { - Support group }\end{array}$ & $\begin{array}{l}\text { - Requires tertiary staff to come } \\
\text { through to primary setting }\end{array}$ \\
\hline $\begin{array}{l}\text { Multidisciplinary renal } \\
\text { supportive clinic at a } \\
\text { tertiary centre }\end{array}$ & $\begin{array}{l}\text { - Focused, structured visits prior to } \\
\text { transfer to primary care } \\
\text { - Staff: nephrologist, social worker, } \\
\text { nursing staff, primary healthcare } \\
\text { doctor; access to palliative care } \\
\text { trained physician } \\
\text { - Multidisciplinary team discussions } \\
\text { - Palliative supportive care nurse to } \\
\text { co-ordinate care between primary } \\
\text { and tertiary care facilities } \\
\text { - The focus should be on counselling, } \\
\text { and linking families with social/ } \\
\text { community networks } \\
\text { - Symptom management } \\
\text { - Advanced Care Planning (uses } \\
\text { healthcare document retained by the } \\
\text { patient) }\end{array}$ & $\begin{array}{l}\text { - Provides support to patients not } \\
\text { eligible for renal replacement (formal } \\
\text { care plan) to prevent feelings of } \\
\text { abandonment } \\
\text { - Training platform for doctors, nurses, } \\
\text { social workers } \\
\text { - Upskilling staff and knowledge } \\
\text { transfer } \\
\text { - Upskill nephrologists in palliative } \\
\text { care } \\
\text { - Upskill primary healthcare } \\
\text { physicians in preservation of } \\
\text { residual renal function and CKD } \\
\text { management }\end{array}$ & $\begin{array}{l}\text { - Cost } \\
\text { - Staffing shortages } \\
\text { - Needs space } \\
\text { - Requires primary carer to go across } \\
\text { to tertiary facility }\end{array}$ \\
\hline Access to medication & $\begin{array}{l}\text { - Discussion with Pharmacology and } \\
\text { Therapeutics Committees (PTC) and } \\
\text { provincial health management }\end{array}$ & $\begin{array}{l}\text { - Advocacy to have access to } \\
\text { restricted medications for ESKD } \\
\text { symptom management at all levels of } \\
\text { care (in public sector) } \\
\text { - Advocacy for authorisation of } \\
\text { medications from medical insurance } \\
\text { - Advantage of improved patient } \\
\text { symptom control }\end{array}$ & \\
\hline $\begin{array}{l}\text { Standardised patient } \\
\text { and family Information }\end{array}$ & $\begin{array}{l}\text { - Patient information accessible in } \\
\text { different languages in a culturally } \\
\text { sensitive format } \\
\text { - Highlighting information and } \\
\text { resources available within } \\
\text { communities, e.g. } \\
\text { - Internet/government resources list of } \\
\text { local CHC } \\
\text { - Brochure of NGO resources } \\
\text { - Infographics }\end{array}$ & $\begin{array}{l}\text { - Improved integration of patients with } \\
\text { local resources and NGOs }\end{array}$ & - Cost of set-up \\
\hline $\begin{array}{l}\text { Upskilling nurse } \\
\text { practitioners }\end{array}$ & $\begin{array}{l}\text { - Funding needed to train and employ } \\
\text { nurse practitioners to manage } \\
\text { patients in the community }\end{array}$ & $\begin{array}{l}\text { - Ability to supervise volunteers and } \\
\text { home-based care sisters } \\
\text { - Link a patient into community } \\
\text { support } \\
\text { - Facilitated by primary care physician } \\
\text { supervision }\end{array}$ & $\begin{array}{l}\text { - Funding to train and employ nurse } \\
\text { practitioners }\end{array}$ \\
\hline
\end{tabular}


both for support and to achieve integration through collaboration [54]. Upskilling community-based nurse practitioners to train, monitor and supervise lay counsellors and volunteers (or home-based carers) remains a viable option to care within our communities. Table 3 describes possible solutions for creating a renal supportive care clinic.

\section{SPECIAL CONSIDERATIONS IN PAEDIATRIC PATIENTS}

\section{Decision making around renal replacement therapy}

The overriding ethical principle in paediatrics is the "best interests of the child" standard, where the burden and benefit of an intervention such as RRT are considered [55]. The preferred mode of dialysis in children is peritoneal dialysis as it facilitates normal school, family and play activities [56]. However, each family needs to be assessed in their context to decide which pathway of care would be in their best interest. This assessment is influenced by community infrastructure, family stability, financial resources, existing healthcare systems, compliance record, and quality of life. Methods of communicating information to children at different neurodevelopmental stages and with varying capacity need to be considered.

\section{Management options for children with ESKD [57]}

- Pre-emptive kidney transplantation is the ideal treatment for suitable patients and in most cases implies live related kidney transplantation

- Peritoneal dialysis

- Haemodialysis including home haemodialysis

- Renal supportive care without dialysis.

\section{Choice of treatment modality}

The choice of treatment modality should be decided upon by considering the following factors [57]:

- Contraindications to a specific form of dialysis

- Caregiver/parent and patient preference (where applicable)

- Quality of life factors of patient and family including siblings

- Treating practitioner's advice (including nursing and allied health).

\section{Suitability for renal replacement therapy}

In lower- and middle-income countries, psychosocial and economic factors may play a larger role in the selection financial payment of treatments [58,59]. If a child is not a suitable RRT candidate, one needs to question the value of continuing dialysis, as it has the potential to prolong dying rather than to improving quality of life [55]. The burden of dialysis can outweigh the benefits of providing treatment and violates the medical maxim of maleficence (do no harm). It is appropriate to withdraw or not to initiate dialysis in children if the dialysis is harmful, is of no benefit or prolongs the dying process [60]. Harm may include psychosocial factors such as institutionalisation, family fragmentation, financial destitution or isolation from culture and community.

RSC/PC should then be considered during a shared decision-making process. However, it is essential that the nuclear family and, if possible, the extended family be involved in the decision-making process. Neonates and infants with ESKD and comorbid conditions have a poorer prognosis and are a challenge from an access and surgical aspect. RSC/PC may often be the care pathway for many patients in this group. Psychosocial support, including anticipatory bereavement, peri-natal advance care planning and memory work, should be integrated into their management plan from the time of diagnosis [6I]. Shared decision making is encouraged in conjunction with a multidisciplinary team and, potentially, an appointed neutral parent or family member as in the SONG-Kids initiative (www.songinitiative.org) [55].

\section{Renal transplantation}

The goal to provide a renal transplant is in line with the United Nations Convention on the Rights of the Child, that states that children have the right to live and enjoy the highest attainable standard of health, and governments should ensure that children survive and develop healthily [62]. Care of a renal graft requires strictly defined boundaries and dependence on life-long compliance to medication, medical surveillance and significant life-style adaptations [63]. Each transplant centre should have its own pathway of care to ensure a successful transplant. Centre-specific guidelines should advocate that patients and their families be fully informed about diagnosis, prognosis and treatment options.

\section{The role of paediatric palliative care in paediatric renal supportive care}

Paediatric palliative care (PPC) provides an active approach to reduce disease burden and improve quality of life for both the child and family, through formulation of management plans by a multidisciplinary team. These plans address distressing symptoms in different domains of well-being: physical, spiritual, social, cultural and psychological. Offering 
early PPC as an integral part of paediatric renal supportive care (RSC) should be done routinely $[64,65]$.

Active palliative care interventions include symptom management, medical and prognostic counselling, facilitation of family meetings and discussion of ethics, advance care planning as well as difficult discussions about end-of-life care. Resuscitation status, terminal care and bereavement support should also be addressed. Families that are receiving $\mathrm{RSC}$ often request pain management, clarification of treatment goals and relief from emotional and social distress as well as management of the patient's siblings [66].

RSC requires clinicians, allied health and psychosocial team members with generalist palliative care training to achieve comprehensive care [64]. PPC specialists are rare in lower- and lower-middle-income countries (LLMIC), so it is imperative that the generalist paediatrician (or general practitioner) adopt a palliative care approach so that it is incorporated into the multidisciplinary team [67]. The demand for generalist health professional knowledge and skills in PPC is growing in response to heightened recognition of the benefits of a palliative approach across the neonatal, paediatric and adolescent lifespan. Unfortunately, there is still no government paediatric palliative care policy implementation in South Africa. Paediatric palliative care in South Africa is currently provided by the NGO sector.

Ongoing advocacy from the nephrology community to develop PPC education projects would elevate the quality of RSC. Themes emerging from PPC education projects include [68]:

- Building capability in PPC

- Developing inter-professional partnerships

- Sustaining staff well-being

- Learning from children and families including siblings.

Delivery of PPC education can range from didactic to interactive engagement and may coincide with developing mentoring models between specialist PPC teams and nephrology teams. Nephrology teams need to develop sustainable models for providing PPC in the RSC pathway.

Table 4. Symptom management in children.

\begin{tabular}{|c|c|c|c|}
\hline Symptoms & Causes & Drug and doses & Comments \\
\hline Nausea and vomiting & $\begin{array}{l}\text { Uraemia, metabolic acidosis, } \\
\text { gastric paresis, constipation }\end{array}$ & $\begin{array}{l}\text { Odansetron 2-4 mg, 8-h. } \\
\text { Lactulose/sorbitol prn; Movicol half to } \\
\text { I sachet }\end{array}$ & $\begin{array}{l}\text { This may have long-term issues and a } \\
\text { dietitian's input is useful. }\end{array}$ \\
\hline Poor appetite & Uraemia, pill burden, behavioural & $\begin{array}{l}\text { Allow child to eat what he/she enjoys } \\
\text { and avoid meal battles } \\
\text { NG tube, gastrostomy, overnight feeds, } \\
\text { cyproheptadine (Ciplactin), } 4 \text { mg daily } \\
\text { (this is an antihistamine so may cause } \\
\text { drowsiness) }\end{array}$ & $\begin{array}{l}\text { Include family input and do not force } \\
\text { food that is not enjoyed. }\end{array}$ \\
\hline Pain & Depending on region and cause & $\begin{array}{l}\text { Fentanyl I-4 } \mu \mathrm{g} / \mathrm{kg} / \mathrm{h} \mathrm{IVI} \text { infusion. } \\
\text { Paracetamol } 10 \mathrm{mg} / \mathrm{kg} \text {, 6-h. } \\
\text { Gabapentin } 2 \mathrm{mg} / \mathrm{kg} \text { and titrate up }\end{array}$ & $\begin{array}{l}\text { Morphine is cleared slowly and may } \\
\text { accumulate.Valeron drops if available. May } \\
\text { need to stagger different drug dosing. }\end{array}$ \\
\hline Tetany and bone pain & $\begin{array}{l}\text { Electrolyte abnormalities, } \\
\text { e.g. Ca and } \mathrm{Mg}\end{array}$ & $\begin{array}{l}\text { Calcium gluconate } 0.5 \mathrm{ml} / \mathrm{kg} \text { slow IVI. } \\
\text { Magnesium chloride } 0.4 \mathrm{ml} / \mathrm{kg} \mathrm{IVI} \text {. } \\
\text { One-Alpha ( } \alpha \text {-hydroxyvitamin } \mathrm{D}_{3} \text { ) } 0.25 \text { - } \\
\text { I.0 } \mathrm{\mu g} / \text { dose oral. }\end{array}$ & $\begin{array}{l}\text { Ideally, need cardiac monitor or infuse } \\
\text { over I hour. } \\
\text { Attempt to give oral calcium } \\
\text { (Calcium Sandoz), half to I effervescent } \\
\text { tablet per dose. } \\
\text { Magnesium [magnesium chloride oral } \\
\text { suspension ( } 440 \mathrm{mg}=5 \mathrm{~mL} \text { ), } 50 \mathrm{mg} / \mathrm{kg} / \\
\text { day in divided doses]. }\end{array}$ \\
\hline Seizures & $\begin{array}{l}\text { PRES (due to hypertension) or } \\
\text { electrolyte abnormalities }\end{array}$ & $\begin{array}{l}\text { Treat hypertension or electrolytes. } \\
\text { Phenobarbitone 10-20 mg/dose to max } \\
\text { of } 200 \text { mg per dose/Diazepam 0. I-0.2 } \\
\text { mg/kg or IVI titrated slowly per rectum. }\end{array}$ & Buccal midazolam $0.1-0.2$ mg/kg. \\
\hline Sleep disturbances & Poor sleep-wake cycle, anxiety & $\begin{array}{l}\text { Melatonin 3-5 mg/dose. } \\
\text { Clonidine I-2 } \mu \mathrm{g} / \mathrm{kg} \text {, } 8-\mathrm{h} \text { and increase to } \\
5 \mu \mathrm{g} / \mathrm{kg} \text {. }\end{array}$ & $\begin{array}{l}\text { Aromatherapy and music therapy also } \\
\text { useful. }\end{array}$ \\
\hline Anxiety and sadness & & $\begin{array}{l}\text { Play therapy } \\
\text { Counsellor } \\
\text { Antidepressants (citalopram } 10 \text { mg/kg) }\end{array}$ & $\begin{array}{l}\text { Ideally, psychiatric services should be } \\
\text { involved. }\end{array}$ \\
\hline
\end{tabular}


Where consultation may be required with specialty palliative care during renal supportive care

- Management of refractory pain or other symptoms

- Management of more complex depression, anxiety, grief, and existential distress

- Assistance with conflict resolution regarding goals or methods of treatment within families or between staff

- Assistance in addressing cases of near-futility measures

- Support of staff who are caring for these children.

\section{Specific paediatric requirements for symptom} management (Table 4)

- In the setting of paediatrics, many drugs may only be available on Section 21 application. In cases where important drugs are not available, advocacy may be required to gain access to these agents.

- Devices for ease of drug administration need to be considered including nasogastric tubes or percutaneous endoscopic gastrostomies (PEGs) inserted for chronic use.

- May need intravenous access for specific symptoms such as tetany.

\section{RSC PRIMARY PALLIATIVE CARE SKILLS FOR NEPHROLOGY TEAMS:A RECOMMENDED MODEL}

- Basic management of pain and symptoms

- Basic management of depression and anxiety

- Basic discussions about prognosis

- Discussion and development of goals of treatment

- Resuscitation status discussion and precise documentation of what can and cannot be offered (for example, high-flow oxygen but not bag mask ventilation and intubation).

Palliative care structures in paediatric nephrology are often insufficient. Barriers to establishing a palliative care approach in conservative care in ESKD include [69]:

- Insufficient expertise

- Lack of training regarding end-of-life care and death

- Lack of adequate funding

- Lack of time

- Lack of cooperation with specialised palliative care teams

- Lack of in-house palliative care structures.

Evolving RSC teams should prioritise training in complex communication, strengthening interdisciplinary support

systems and further palliative care education [66].

\section{CONCLUSIONS}

Proposed research agenda (adults and paediatrics)

- Determine the actual number of patients who require palliative and supportive care due to ESKD. This should be accompanied by a needs assessment of the ESKD patient and their families so as to develop a strategic and comprehensive approach to address the unique needs of our country within our available resources.

- Study the relevance of internationally recognized communication tools in our South African context.

- Develop prognostic measures for our setting given our unique cultural and ethnic diversity. Further research, especially in resource-limited environments with a high burden of disease, should be encouraged.

- Determine outcomes of effective supportive care in different categories of ESKD patients, whether on dialysis or not.

- Compile a multi-centre symptom inventory (e.g. IPOSRenal) of dialysis patients in both the public and private sectors.

- Aim to understanding the special needs of paediatrics within these frameworks.

\section{Recommendations}

- Upskill healthcare workers in essential communication skills.

- Establish the role of medical insurance societies in palliative and supportive care in ESKD.

- Highlight the hidden costs of dialysis that are not often included by some medical insurers.

- Explore better arrangements for the provision of hidden costs, such as packaged care models.

- Acknowledge that multidisciplinary cover should be included in the dialysis costs (for the services of a dietician, psychologist, social worker, access, etc.).

- Basic medical insurance cover:

- When to join?

- What is provided?

- Motivate for all the required medication at primary healthcare level.

- Extend the Essential Drugs List.

- In view of the limited access to RRT, we advocate that renal supportive care should be supported by government.

- Fund renal supportive care nurses and their training. 


\section{REFERENCES}

I. Sepúlveda C, Marlin A, Yoshida T, Ullrich A. Palliative care: the World Health Organization's global perspective. J Pain Symptom Manage. 2002; 24(2):91-96.

2. South African National Department of Health (2017). National Health Insurance for South Africa. Towards universal health coverage. Government Gazette No. 40955, 30 June 2017.

3. World Health Organization. Health Financing. https://www.who.int/ health_financing/universal_coverage_definition/en/. Accessed 16 September 2019.

4. Davids MR, Marais N, Jacobs JC. South African Renal Registry Annual Report 2015. Afr J Nephrol. 2017; 20(1):201-2I3.

5. Wachterman MW, Marcantonio ER, Davis RB, Cohen RA, Waikar SS, Phillips RS, et al. Relationship between the prognostic expectations of seriously ill patients undergoing hemodialysis and their nephrologists. JAMA Intern Med. 20 13; 173(13):I206-12I4.

6. Cohen LM, Ruthazer R, Moss AH, Germain MJ. Predicting six-month mortality for patients who are on maintenance hemodialysis. Clin J Am Soc Nephrol. 20 I0; 5(1):72-79.

7. Couchoud C, Labeeuw M, Moranne O, Allot V, Esnault V, Frimat L, et al. A clinical score to predict 6-month prognosis in elderly patients starting dialysis for end-stage renal disease. Nephrol Dial Transpl. 2009; 24(5):| 553-|56|.

8. Stewart B, Brown JB, Weston WW, et al. Patient centered medicine: transforming the clinical method. 2nd ed. Oxford: Radcliff Medical Press; 2003.

9. Mead N, Bower P. Patient-centredness: a conceptual framework and review of the empirical literature. Soc Sci Med. 2000; 5 I (7): 1087-1110.

10. NHS Lothian and The University of Edinburgh Primary Palliative Care Research Group. Supportive and Palliative Care Indicators Tool (SPICT TM $)$. University of Edinburgh; 2015.

11. Highet G, Crawford D, Murray SA, Boyd K. Development and evaluation of the Supportive and Palliative Care Indicators Tool (SPICT): a mixed-methods study. BMJ Support Palliat Care. 2014; 4(3):285-290.

12. Tangri N, Ferguson T, Komenda P. Pro: risk scores for chronic kidney disease progression are robust, powerful and ready for implementation. Nephrol Dial Transplant. 20 I7; 32(5):748-75 I.

13. Major recommendations. Establishing a shared decision-making relationship. In: Shared decision-making in the appropriate initiation and withdrawal from dialysis. 2nd ed. www.guidelinecentral.com/ summaries/guideline-recommendations-and-their-rationales-for-thetreatment-of-adult-patients-in-shared-decision-making-in-theappropriate-initiation-of-and-withdrawal-from-dialysis-2ndedition/\#section-420. Accessed 25 September 2019.

14. Hemmelgarn BR, Manns BJ, Quan H, Ghali WA. Adapting the Charlson Comorbidity Index for use in patients with ESRD. Am J Kidney Dis. 2003; 42( I): I 25- 132.

15. Abernethy AP, Shelby-James T, Fazekas BS, Woods D, Currow DC. The Australia-modified Karnofsky Performance Status (AKPS) scale: a revised scale for contemporary palliative care clinical practice [ISRCTN8 I I I 748 I] BMC Palliat Care. 2005; 4(I):7.

16. Davison SN, Levin A, Moss AH, Jha V, Brown EA, Brennan F, et al. Executive summary of the KDIGO Controversies Conference on Supportive Care in Chronic Kidney Disease: developing a roadmap to improving quality care. Kidney Int. 20 I5; 88(3):447-459.

17. Hearn J, Higginson IJ. Development and validation of a core outcome measure for palliative care: the palliative care outcome scale. Palliative Care Core Audit Project Advisory Group. Qual Health Care. 1999; 8(4):219-227.

18. Murphy EL, Murtagh FE, Carey I, Sheerin NS. Understanding symptoms in patients with advanced chronic kidney disease managed without dialysis: use of a short patient-completed assessment tool. Nephron Clin Pract. 2009; 1 I I ( I):c74-80.
19. Raj R, Ahuja K, Frandsen M, Murtagh FE, Jose M. Validation of the IPOS-Renal Symptom Survey in advanced kidney disease: a cross-sectional study. J Pain Symptom Manage. 20 I 8; 56(2):28 I-287.

20. Davison S. Edmonton Zone Palliative Care Program and Northern Alberta Renal Program; 20 16. http://www palliativeorg/toolshtml. Accessed August 2019.

2I. Tan G, Jensen MP, Thornby JI, Shanti BF. Validation of the Brief Pain Inventory for chronic nonmalignant pain. J Pain. 2004; 5(2): I33-I 37.

22. Davison SN, Tupala B, Wasylynuk BA, Siu V, Sinnarajah A, Triscott J. Recommendations for the care of patients receiving conservative kidney management: focus on management of CKD and symptoms. Clin J Am Soc Nephrol. 2019; 14(4):626-634.

23. PCF6: palliative care formulary. 6th ed. Twycross RG, Wilcock A, Howard P, editors. Nottingham: Palliativedrugs.com Ltd; 2017.

24. Nagler EV, Webster AC, Vanholder R, Zoccali C. Antidepressants for depression in stage 3-5 chronic kidney disease: a systematic review of pharmacokinetics, efficacy and safety with recommendations by European Renal Best Practice (ERBP). Nephrol Dial Transplant. 2012; 27(I0):3736-3745.

25. Palmer S, Vecchio M, Craig JC, Tonelli M, Johnson DW, Nicolucci A, et al. Prevalence of depression in chronic kidney disease: systematic review and meta-analysis of observational studies. Kidney Int. 2013; 84(I): 179-191.

26. Cukor D, Ver Halen N, Asher DR, Coplan JD, Weedon J, Wyka KE, et al. Psychosocial intervention improves depression, quality of life, and fluid adherence in hemodialysis. J Am Soc Nephrol. 2014; 25(I): 196-206.

27. Duarte PS, Miyazaki MC, Blay SL, Sesso R. Cognitive-behavioral group therapy is an effective treatment for major depression in hemodialysis patients. Kidney Int. 2009; 76(4):414-421.

28. Ouzouni S, Kouidi E, Sioulis A, Grekas D, Deligiannis A. Effects of intradialytic exercise training on health-related quality of life indices in haemodialysis patients. Clin Rehabil. 2009; 23(1):53-63.

29. Levendoglu F, Altintepe L, Okudan N, Ugurlu H, Gokbel H, Tonbul Z, et al. A twelve week exercise program improves the psychological status, quality of life and work capacity in hemodialysis patients. J Nephrol. 2004; 17(6):826-832.

30. Noble H, Meyer PJ, Bridge DJ, Johnson DB, Kelly DD. Exploring symptoms in patients managed without dialysis: a qualitative research study. J Ren Care. 20 I0; 36(1):9-15.

31. Murtagh FE, Addington-Hall JM, Edmonds PM, Donohoe P, Carey I, Jenkins K, et al. Symptoms in advanced renal disease: a crosssectional survey of symptom prevalence in stage 5 chronic kidney disease managed without dialysis. J Palliat Med. 2007; 10(6): 1266-1276.

32. Davison SN, Koncicki H, Brennan F. Pain in chronic kidney disease: a scoping review. Semin Dial. 20I4; 27(2): I 88-204.

33. Davison $\mathrm{SN}$. Clinical pharmacology considerations in pain management in patients with advanced kidney failure. Clin J Am Soc Nephrol. 2019; 14(6):917-931.

34. McMurray JJ, Parfrey PS, Adamson JW, Aljama P, Berns JS, Bohlius J, et al. Kidney Disease: Improving Global Outcomes (KDIGO) anemia work group. KDIGO clinical practice guideline for anemia in chronic kidney disease. Kidney Int Suppl. 20 I2; 2(4):279-335.

35. Novak M, Mendelssohn D, Shapiro CM, Mucsi I. Diagnosis and management of sleep apnea syndrome and restless legs syndrome in dialysis patients. Semin Dial. 2006; 19(3):210-216.

36. Baile WF, Buckman R, Lenzi R, Glober G, Beale EA, Kudelka APJTo SPIKES - a six-step protocol for delivering bad news: application to the patient with cancer. 2000; 5(4):302-31 I.

37. Bernacki R, Block SD. Communication about serious illness care goals: a review and synthesis of best practices. JAMA Intern Med. 2014; 174(12): 1994-2003. 
38. Buckman R. Communication skills. In: Emanuel LL, Librach SL, editors. Palliative care: core skills and clinical competencies. 2nd ed. St Louis, Missouri: Elsevier; 201।.

39. Serious Illness Conversation Guide. Ariadne Labs; 2017. https:// www.ariadnelabs.org/wp-content/uploads/sites/2/2017/05/ SI-CG-2017-04-2I_FINAL.pdf. Accessed I5 April 2020.

40. Kidney Disease: Improving Global Outcomes (KDIGO) CKD Work Group. KDIGO 2012 clinical practice guideline for the evaluation and management of chronic kidney disease. Kidney Int Suppl. 2013;3(I)I-150.

4I. Levin A, Stevens PE. Summary of KDIGO 2012 CKD Guideline: behind the scenes, need for guidance, and a framework for moving forward. Kidney Int. 20 4 4; 85(I):49-6I.

42. Seedat $Y$, Rayner B, Veriava $Y$. South African hypertension practice guideline 20 4. Cardiovasc J Afr. 20 I4; 25(6):288-294.

43. de Brito-Ashurst I, Varagunam M, Raftery MJ, Yaqoob MM. Bicarbonate supplementation slows progression of CKD and improves nutritional status. J Am Soc Nephrol. 2009; 20(9):2075-2084

44. Ketteler M, Block GA, Evenepoel P, Fukagawa M, Herzog CA, McCann L, et al. Executive summary of the 2017 KDIGO chronic kidney disease-mineral and bone disorder (CKD-MBD) guideline update: what's changed and why it matters. Kidney Int. 2017; 92(I):26-36.

45. Committee STDGE. SEMDSA 2017 guidelines for the management of type 2 diabetes mellitus. J Endocr Metab Diabetes S Afr. 2017; 22( ( Suppl I):SI-S196.

46. Kutner JS, Blatchford PJ, Taylor DH, Jr., Ritchie CS, Bull JH, Fairclough $\mathrm{DL}$, et al. Safety and benefit of discontinuing statin therapy in the setting of advanced, life-limiting illness: a randomized clinical trial. JAMA Intern Med. 20।5; 175(5):691-700.

47. Benetos A, Rossignol P, Cherubini A, Joly L, Grodzicki T, Rajkumar $C$, et al. Polypharmacy in the Aging patient: management of hypertension in octogenarians. JAMA. 2015; 3|4(2): 170-180

48. Cherny N. Oxford textbook of palliative medicine. 5th ed. Cherny $\mathrm{NI}$, editor. Oxford: Oxford University Press; 2015.

49. Smith S, Brick A, O'Hara S, Normand C. Evidence on the cost and cost-effectiveness of palliative care: a literature review. Palliat Med. 20|4; 28(2):130- 150

50. Murray AM, Arko C, Chen SC, Gilbertson DT, Moss AH. Use of hospice in the United States dialysis population. Clin J Am Soc Nephrol. 2006; I (6): I248- 1255

5I. Maddalena V, O'Shea F, Barrett B. An exploration of palliative care needs of people with end-stage renal disease on dialysis: family caregiver's perspectives. J Palliat Care. 2018; 33(1):19-25.

52. Scott D, Hudson P, Charnley K, Payne C, Westcott G. Development of an eHealth information resource for family carers supporting a person receiving palliative care on the island of Ireland. BMC Palliat Care. 2019; 18(1):74

53. Vanderstichelen S, Cohen J, Van Wesemael Y, Deliens L, Chambaere K. Perspectives on volunteer-professional collaboration in palliative care: a qualitative study among volunteers, patients, family carers, and health care professionals. J Pain Symptom Manage. 2019; 58(2):198-207.

54. Dionne JM, d'Agincourt-Canning L. Sustaining life or prolonging dying? Appropriate choice of conservative care for children in end-stage renal disease: an ethical framework. Pediatr Nephrol. 2015; 30(10):1761-1769.

55. Chaudhary K, Sangha H, Khanna R. Peritoneal dialysis first: rationale. Clin J Am Soc Nephrol. 20 I I; 6(2):447-456.

56. Van Biljon I, Bhimma R, Gajjar P, McCulloch M, Nourse P. Guideline for chronic dialysis in children in South Africa. http://sa-renalsociety. org/wp-content/uploads/20 I 8/03/SARS-Guideline2_ChronicDialysisChildren_2015.pdf.
57. Anderson K, Cass A, Cunningham J, Snelling P, Devitt J, Preece C. The use of psychosocial criteria in Australian patient selection guidelines for kidney transplantation. Soc Sci Med. 2007; 64(10):2107-21।4.

58. Giacomini MK, Cook DJ, Streiner DL, Anand SS. Using practice guidelines to allocate medical technologies: an ethics framework. Int J Technol Assess Health Care. 2000; 16(4):987-1002.

59. Galla JH. Clinical practice guideline on shared decision-making in the appropriate initiation of and withdrawal from dialysis. J Am Soc Nephrol. 2000; II (7): I340-1 342.

60. Rees L. Management of the infant with end-stage renal failure. Nephrol Dial Transplant. 2002; 17(9):I564-1567.

6I. UNICEF. UN convention on child rights fact sheet; 20I8. https:// www.unicef.org/crc/files/Rights_overview.pdf.

62. Riaño I, Malaga S, Callis L, Loris C, Martin-Govantes J, Navarro M, et al. Towards guidelines for dialysis in children with end-stage renal disease. Pediatr Nephrol. 2000; I5(I-2): 157- 162.

63. Thumfart J, Reindl T, Rheinlaender C, Müller D. Supportive palliative care should be integrated into routine care for paediatric patients with life-limiting kidney disease. Acta Paediatr. 2018; 107(3):403-407.

64. Standardised Outcomes in Nephrology - Children and Adolescents (SONG-Kids). www.songinitiative.org.

65. Keefer P, Lehmann K, Shanley M, Woloszyk T, Khang E, Luckritz K, et al. Single-center experience providing palliative care to pediatric patients with end-stage renal disease. J Palliat Med. 2017; 20(8):845-849.

66. Quill TE, Abernethy AP. Generalist plus specialist palliative care-creating a more sustainable model. New Engl J Med. 2013; 368(13):1173-1175.

67. Donovan LA, Slater PJ, Baggio SJ, McLarty AM, Herbert AR. Perspectives of health professionals and educators on the outcomes of a national education project in pediatric palliative care: the Quality of Care Collaborative Australia. Adv Med Medical Educ Pract. 2019; 10:949.

68. Thumfart J, Bethe D, Wagner S, Pommer W, Rheinländer C, Müller D. A survey demonstrates limited palliative care structures in paediatric nephrology from the perspective of a multidisciplinary healthcare team. Acta Paediatr. 20 |9; I08(7):| 350- I 356.

69. Hall WH, Ramachandran R, Narayan S, Jani AB, Vijayakumar S. An electronic application for rapidly calculating Charlson comorbidity score. BMC Cancer. 2004; 4(I):94. 


\section{ADDENDA}

\section{Addendum I: Charlson Comorbidity Index.}

The Charlson Index was developed in 1987 and is based on I-year mortality data from internal medicine patients admitted to a single New York Hospital. It was initially validated in a cohort of breast cancer patients. The index encompasses 19 medical conditions weighted I-6 with total scores ranging from 0-37. In the development phase of the index, mortality for each disease was converted to a relative risk of death within 12 months. A weight was then assigned to each condition based on the relative risk (RR); for example, $R R<1.2$ = weight $0 ; R R \geq 1.2<1.5=$ weight $1 ; R R \geq 1.5<2.5$ = weight 2; $R R \geq 2.5<3.5$ = weight 3; and for 2 conditions (metastatic solid tumour and AIDS) = weight 6 (70).

\begin{tabular}{|c|c|}
\hline Comorbidity & Score \\
\hline Prior myocardial infarction & । \\
\hline Congestive heart failure & । \\
\hline Peripheral vascular disease & । \\
\hline Cerebrovascular disease & I \\
\hline Dementia & । \\
\hline Chronic pulmonary disease & । \\
\hline Rheumatologic disease & । \\
\hline Peptic ulcer disease & । \\
\hline Mild liver disease & । \\
\hline Diabetes & । \\
\hline Cerebrovascular (hemiplegia) event & 2 \\
\hline Moderate-to-severe renal disease & 2 \\
\hline Diabetes with chronic complications & 2 \\
\hline Cancer without metastases & 2 \\
\hline Leukemia & 2 \\
\hline Lymphoma & 2 \\
\hline Moderate or severe liver disease & 3 \\
\hline Metastatic solid tumor & 6 \\
\hline Acquired immuno-deficiency syndrome (AIDS) & 6 \\
\hline
\end{tabular}

doi: I0. I 37 |/journal.pone.0 I 54627.t003 


\section{Addendum 2: Karnofsky Performance Scale.}

The Karnofsky Performance Scale allows patients to be classified according to their functional impairment. This can be used to compare effectiveness of different therapies and to assess the prognosis in individual patients. The lower the Karnofsky score, the worse the survival for most serious illnesses.

\section{KARNOFSKY PERFORMANCE STATUS SCALE DEFINITIONS RATING (\%) CRITERIA}

\begin{tabular}{|c|c|c|}
\hline \multirow{3}{*}{$\begin{array}{l}\text { Able to carry on normal activity and to work; no special } \\
\text { cared needed. }\end{array}$} & 100 & Normal no complaints; no evidence of disease. \\
\hline & 90 & $\begin{array}{l}\text { Able to carry on normal activity; minor signs or } \\
\text { symptoms of disease. }\end{array}$ \\
\hline & 80 & $\begin{array}{l}\text { Normal activity with effort; some signs or symptoms of } \\
\text { disease. }\end{array}$ \\
\hline \multirow{3}{*}{$\begin{array}{l}\text { Unable to work; able to live at home and care for most } \\
\text { personal needs; varying amount of assistance needed. }\end{array}$} & 70 & $\begin{array}{l}\text { Cares for self; unable to carry on normal activity or to do } \\
\text { active work. }\end{array}$ \\
\hline & 60 & $\begin{array}{l}\text { Requires occasional assistance, but is able to care for } \\
\text { most of his personal needs. }\end{array}$ \\
\hline & 50 & $\begin{array}{l}\text { Requires considerable assistance and frequent } \\
\text { medical care. }\end{array}$ \\
\hline \multirow{5}{*}{$\begin{array}{l}\text { Unable to care for self; requires equivalent of } \\
\text { institutional or hospital care; disease may be } \\
\text { progressing rapidly. }\end{array}$} & 40 & Disabled; requires special care and assistance. \\
\hline & 30 & $\begin{array}{l}\text { Severely disabled, hospital admission is indicated although } \\
\text { death not imminent. }\end{array}$ \\
\hline & 20 & $\begin{array}{l}\text { Very sick; hospital admission necessary; active supportive } \\
\text { treatment necessary. }\end{array}$ \\
\hline & 10 & Moribund; fatal processes progressing rapidly. \\
\hline & 0 & Dead \\
\hline
\end{tabular}

\section{REFERENCES:}

Crooks V, Waller S, et al. The use of the Karnofsky Performance Scale in determining outcomes and risk in geriatric outpatients. J Gerontol. 1991; 46:MI39-MI44.

de Haan R, Aaronson A, et al. Measuring quality of life in stroke. Stroke. 1993; 24:320-327.

Hollen PJ, Gralla RJ, et al. Measurement of quality of life in patients with lung cancer in multicenter trials of new therapies. Cancer. 1994; 73:2087-2098.

O'Toole DM, Golden AM. Evaluating cancer patients for rehabilitation potential. West J Med. 1991; 155:384-387.

Oxford Textbook of Palliative Mediicine, Oxford University Press. 1993; 109.

Schag CC, Heinrich RL, Ganz PA. Karnofsky performance status revisited: Reliability, validity, and guidelines. J Clin Oncology. 1983; 2:187-193. 
Addendum 3: IPOS-Renal.

\section{IPOS-RENAL PATIENT VERSION}

Patient name:

Date $(\mathrm{dd} / \mathrm{mm} / \mathrm{yyyy})$ :

Patient number:

(for staff use)

QI. What have been your main problems or concerns over the past 3 days?

I.

2.

3.

Q2. Below is a list of symptoms, which you may or may not have experienced. For each symptom, please tick the box that best describes how it has affected you over the past 3 days.

\begin{tabular}{|c|c|c|c|c|c|}
\hline & Not at all & Slightly & Moderately & Severely & Overwhelmingly \\
\hline Pain & $0 \square$ & $1 \square$ & $2 \square$ & $3 \square$ & $4 \square$ \\
\hline Shortness of breath & $0 \square$ & $1 \square$ & $2 \square$ & $3 \square$ & $4 \square$ \\
\hline $\begin{array}{l}\text { Weakness or lack } \\
\text { of energy }\end{array}$ & $0 \square$ & $1 \square$ & $2 \square$ & $3 \square$ & $4 \square$ \\
\hline $\begin{array}{l}\text { Nausea (feeling like you } \\
\text { are going to be sick) }\end{array}$ & $0 \square$ & $1 \square$ & $2 \square$ & $3 \square$ & $4 \square$ \\
\hline Vomitting (being sick) & $0 \square$ & $1 \square$ & $2 \square$ & $3 \square$ & $4 \square$ \\
\hline Poor appetite & $0 \square$ & $\mathrm{I} \square$ & $2 \square$ & $3 \square$ & $4 \square$ \\
\hline Constipation & $0 \square$ & $1 \square$ & $2 \square$ & $3 \square$ & $4 \square$ \\
\hline Sore or dry mouth & $0 \square$ & $1 \square$ & $2 \square$ & $3 \square$ & $4 \square$ \\
\hline Drowsiness & $0 \square$ & $1 \square$ & $2 \square$ & $3 \square$ & $4 \square$ \\
\hline Poor mobility & $0 \square$ & $1 \square$ & $2 \square$ & $3 \square$ & $4 \square$ \\
\hline Itching & $0 \square$ & $1 \square$ & $2 \square$ & $3 \square$ & $4 \square$ \\
\hline Difficulty sleeping & $0 \square$ & $1 \square$ & $2 \square$ & $3 \square$ & $4 \square$ \\
\hline $\begin{array}{l}\text { Restless legs or difficulty } \\
\text { keeping legs still }\end{array}$ & $0 \square$ & $\mathrm{।} \square$ & $2 \square$ & $3 \square$ & $4 \square$ \\
\hline Changes in skin & $0 \square$ & $1 \square$ & $2 \square$ & $3 \square$ & $4 \square$ \\
\hline Diarrhoea & $0 \square$ & $1 \square$ & $2 \square$ & $3 \square$ & $4 \square$ \\
\hline
\end{tabular}

Please list any other symptoms not mentioned above, and tick the box to show how they have affected you over the past 3 days.

\begin{tabular}{|c|c|c|c|c|c|}
\hline I. & $0 \square$ & $1 \square$ & $2 \square$ & 3 & 4 \\
\hline 2. & 0 & $1 \square$ & $2 \square$ & 3 & 4 \\
\hline 3. & $0 \square$ & 1 & $2 \square$ & 3 & 4 \\
\hline
\end{tabular}


OVER THE PAST 3 DAYS:

\begin{tabular}{|c|c|c|c|c|c|}
\hline & Not at all & Occasionally & Sometimes & $\begin{array}{l}\text { Most of } \\
\text { the time }\end{array}$ & Always \\
\hline $\begin{array}{l}\text { Q3. Have you been feeling anxious or } \\
\text { worried about your illness or } \\
\text { treatment? }\end{array}$ & $0 \square$ & $1 \square$ & $2 \square$ & 3[ & $4 \square$ \\
\hline $\begin{array}{l}\text { Q4. Have any of your family or friends } \\
\text { been anxious or worried about you? }\end{array}$ & $0 \square$ & $1 \square$ & $2 \square$ & 3 & $4 \square$ \\
\hline \multirow[t]{2}{*}{ Q5. Have you been feeling depressed? } & $0 \square$ & $1 \square$ & $2 \square$ & $3 \square$ & $4 \square$ \\
\hline & Always & $\begin{array}{l}\text { Most of } \\
\text { the time }\end{array}$ & Sometimes & Occasionally & Not at all \\
\hline Q6. Have you felt at peace? & $0 \square$ & $1 \square$ & $2 \square$ & 3[ & $4 \square$ \\
\hline $\begin{array}{l}\text { Q7: Have you been able to share how } \\
\text { you are feeling with your family or } \\
\text { friends as much as you wanted? }\end{array}$ & $0 \longleftarrow$ & $1 \square$ & $2 \square$ & 3 & $4 \square$ \\
\hline \multirow[t]{2}{*}{$\begin{array}{l}\text { Q8. Have you had as much information as } \\
\text { you wanted? }\end{array}$} & $0 \square$ & $1 \square$ & $2 \square$ & 3[ & $4 \square$ \\
\hline & $\begin{array}{l}\text { Problems } \\
\text { addressed/ } \\
\text { No } \\
\text { problems }\end{array}$ & $\begin{array}{l}\text { Problems } \\
\text { mostly } \\
\text { addressed }\end{array}$ & $\begin{array}{l}\text { Problems } \\
\text { partly } \\
\text { addressed }\end{array}$ & $\begin{array}{l}\text { Problems } \\
\text { hardly } \\
\text { addressed }\end{array}$ & $\begin{array}{l}\text { Problems } \\
\text { not } \\
\text { addressed }\end{array}$ \\
\hline \multirow[t]{2}{*}{$\begin{array}{l}\text { Q9. Have any practical problems resulting } \\
\text { from your illness been addressed? } \\
\text { (such as financial or personal) }\end{array}$} & $0 \square$ & $1 \square$ & $2 \square$ & $3 \square$ & $4 \square$ \\
\hline & None & & $\begin{array}{l}\text { Up to half a day } \\
\text { wasted }\end{array}$ & \multicolumn{2}{|c|}{$\begin{array}{l}\text { More than half } \\
\text { a day wasted }\end{array}$} \\
\hline \multirow{2}{*}{$\begin{array}{l}\text { Q10. How much time do you feel has } \\
\text { been wasted on appointments } \\
\text { relating to your healthcare, } \\
\text { e.g. waiting around for transport } \\
\text { of repeating tests? }\end{array}$} & & & & & \\
\hline & On my & & $\begin{array}{l}\text { With help from a } \\
\text { friend or relative }\end{array}$ & \multicolumn{2}{|c|}{$\begin{array}{l}\text { With help from a } \\
\text { member of staff }\end{array}$} \\
\hline $\begin{array}{l}\text { QII. How did you complete this } \\
\text { questionnaire? }\end{array}$ & & & $\square$ & & $\square$ \\
\hline
\end{tabular}

If you are worried about any of the issues raised on this questionnaire, then please speak to your doctor or nurse. 
Addendum 4: Useful online resources.

\section{SA hypertension guidelines}

https://www.hypertension.org.za/guidelines

\section{Kidney Disease: Improving Global Outcomes}

CKD evaluation and management

https://kdigo.org/guidelines/ckd-evaluation-and-management/

CKD and anaemia

https://kdigo.org/guidelines/anemia-in-ckd/

Blood pressure and CKD

https://kdigo.org/guidelines/blood-pressure-in-ckd/

\section{Assessment tools}

Edmonton Symptom Assessment System Revised Renal (ESAS-r: Renal)

https://www.albertahealthservices.ca/frm-2035I.pdf

Brief Pain Inventory

http://www.npcrc.org/files/news/briefpain_short.pdf

\section{Communication tools}

Serious Illness Conversation guide

https://www.ariadnelabs.org/wp-content/uploads/sites/2/20 I5/08/Serious-IIIness-Conversation-Guide-5.22. 1 5.pdf

\section{Care planning tools}

Hospice Palliative Care Association of South Africa (HPCA) Advance Health Care Planning

https://hpca.co.za/wp-content/uploads/20 19/06/HPCA-Advanced-HealthCare-Planning-Document-20 I 8.pdf

\section{Find a palliative care provider}

https://palprac.org/palliative-care/find-a-provider

\section{Become an associate member of PalPrac}

https://palprac.org/palprac/join-us/ 